\title{
Therapeutic Potential of Cannabis, Cannabidiol, and Cannabinoid-Based Pharmaceuticals
}

\author{
Christopher A. Legare Wesley M. Raup-Konsavage Kent E. Vrana \\ Department of Pharmacology, Penn State College of Medicine, Hershey, PA, USA
}

\section{Keywords}

$\Delta^{9}$-THC $\cdot$ CBD $\cdot$ Medical marijuana $\cdot$ Cannabis · Cannabinoids . Pharmacology · Therapeutics

\begin{abstract}
Background: There is a growing interest in the use of cannabis (and its extracts), as well as CBD oil (hemp extracts containing cannabidiol), for therapeutic purposes. While there is reason to believe that cannabinoids may be efficacious for a number of different diseases and syndromes, there exist limited objective data supporting the use of crude materials (CBD oil, cannabis extracts, and/or cannabis itself). Summa$r y$ : In the present review, we examined data for pure cannabinoid compounds (dronabinol, nabilone, and CBD), as well as partially purified medicinal cannabis extracts (nabiximols), to provide guidance on the potential therapeutic uses of high-THC cannabis and CBD oil. In general, data support a role for cannabis/cannabinoids in pain, seizure disorders, appetite stimulation, muscle spasticity, and treatment of nausea/vomiting. Given the biological activities of the cannabinoids, there may be utility in treatment of central nervous system disorders (such as neurodegenerative diseases, PTSD, and addiction) or for the treatment of cancer. However, those data are much less compelling. Key Message: On
\end{abstract}

balance, there are reasons to support the potential use of medical cannabis and cannabis extract $\left(\Delta^{9}\right.$-THC-dominant or CBD-dominant), but much more careful research is required.

(c) 2022 S. Karger AG, Basel

\section{Background}

There are a growing number of US states and nations that have legalized the use of at least some components of Cannabis sativa for medicinal purposes. Despite this increase in the therapeutic use of these substances, evidence-based data regarding their clinical utility remain incomplete [1]. For the physician, this is a potential barrier to the understanding and recommendation of these treatments [2]. Here, we therefore summarize data supporting cannabis (high $\Delta^{9}$-THC containing cannabis (marijuana) and low $\Delta^{9}$-THC containing cannabis [hemp]), its extracts, and isolated cannabinoid compounds as treatments for human disease.

It is important to note that many cannabinoids, including $\Delta^{9}$-THC, exhibit their physiological and pharma-

Christopher A. Legare and Wesley M. Raup-Konsavage are the first two authors who contributed equally.
Correspondence to:

Wesley M. Raup-Konsavage, wkonsavage @ pennstatehealth.psu.edu 


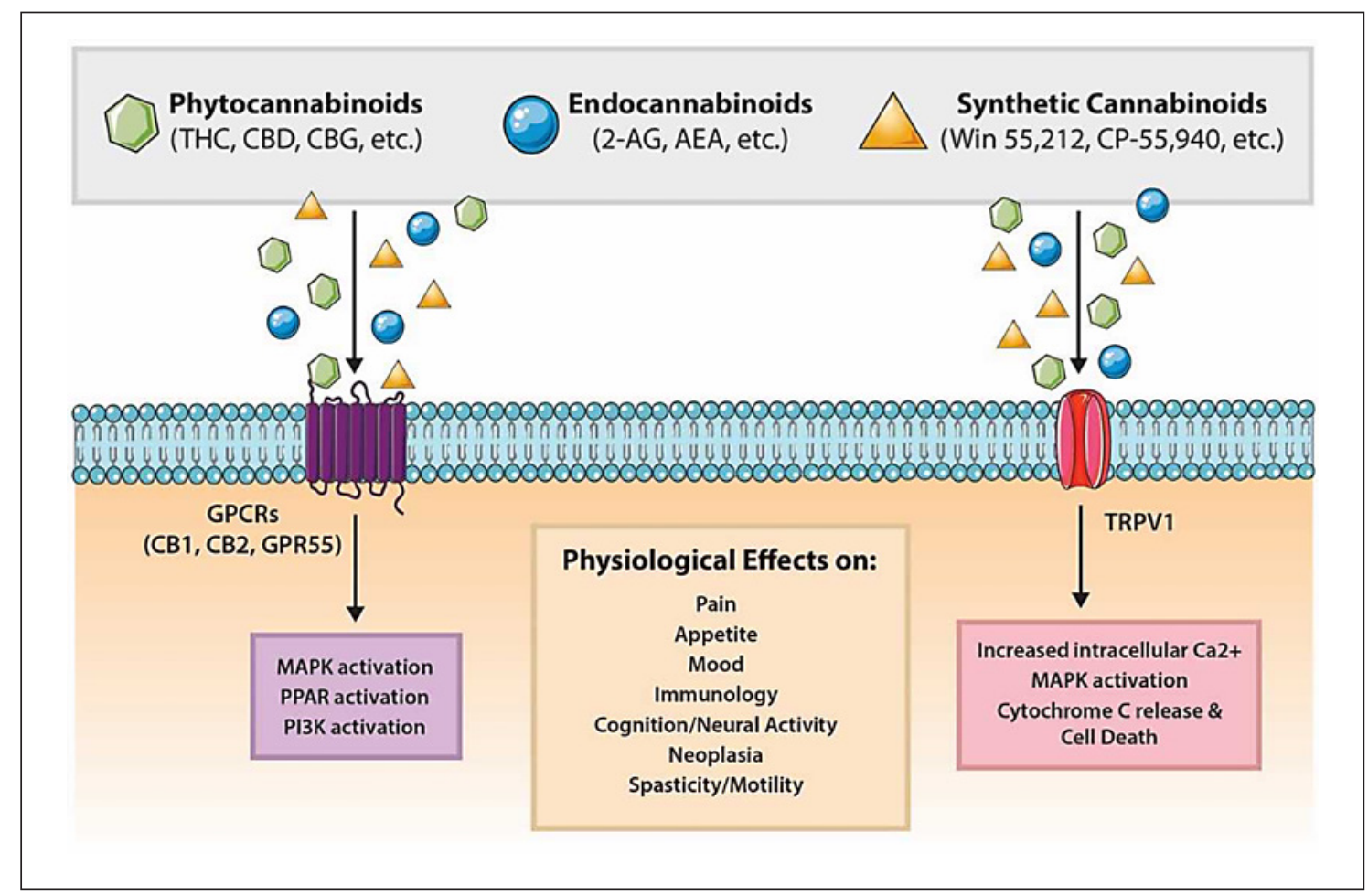

Fig. 1. Cannabinoid signaling pathways and effects. Regardless of the type of cannabinoid ligand (phytocannabinoid, endocannabinoid, or synthetic), these compounds primarily interact with GPCR proteins, such as the CB1 and CB2 receptors and GPR55, or with TRP, such as TRPV1, to induce a cellular response. The pathways activated vary based upon receptor activation and have physiological effects on pain, appetite, mood, and many other effects within the body.

cological effects by engaging the endogenous cannabinoid (endocannabinoid) system (Fig. 1). However, some cannabinoids such as CBD, have low binding affinity for these endogenous receptors and, instead, act outside of the endocannabinoid system [3-6]. The first described endocannabinoid, $\mathrm{N}$-arachidonoylethanolamine (AEA), also known as anandamide, is synthesized from membrane phospholipid precursors [7-9]. Anandamide is a partial agonist at the cannabinoid receptor type 1 (CB1) and cannabinoid receptor type 2 (CB2) receptors at high nanomolar concentrations, a potent partial agonist at the G protein-coupled receptor 55 (GPR55) receptor, and a low-affinity full agonist at the transient receptor potential cation channel subfamily V (TRPV1) calcium channel (Table 1). Additionally, other TRP channels are also known to serve as receptors for cannabinoid ligands along with members of the PPAR, adrenoceptor, and serotonin families of receptors [6, 10-14]. 2-Arachidonoylglycerol (2-AG), the most abundant endocannabinoid, is synthesized from arachidonic acid-containing phosphatidylinositol 4,5-bisphosphate $\left(\mathrm{PIP}_{2}\right)$ [15-17]. Further- more, 2-AG is more efficacious at the $\mathrm{CB} 1, \mathrm{CB} 2$, and GPR55 receptors than AEA; however, with the exception of GPR55 (where it is potent), this molecule has a lower affinity for the cannabinoid receptors than its counterpart (Table 1). Finally, lest we give the impression that the system is simple, it is important to note there are a number of additional putative endocannabinoids [18-21]. Perhaps, the most nuanced aspect of endocannabinoid structure and function is the fact that in contrast to traditional neurotransmitter signaling, the endocannabinoids are synthesized by the target cells (or neighboring support cells such as glia and astrocytes) and released (on demand) as neuromodulators to inhibit presynaptic activity $[22,23]$. Cannabinoids also have functions outside the nervous system, and some of these activities will be discussed throughout this review, but a recent review by Lowe and colleagues [24] details these aspects. Detailed considerations of the biosynthesis, degradation, and pharmacology of the endocannabinoids can be found in a number of excellent recent reviews [23, 25, 26]. Additionally, cannabinoids from cannabis can modulate the 
Table 1. Cannabinoid pharmacology: a compilation of experimental displacement, GTPYS binding, and cytoplasmic (Ca ${ }^{++}$) assay data provides a relative measure of the affinity and efficacy properties of various cannabinoid molecules for major endocannabinoid system receptors

\begin{tabular}{|c|c|c|c|c|c|c|c|c|c|}
\hline \multirow[t]{2}{*}{ Compound } & \multicolumn{2}{|l|}{$\mathrm{CB} 1$} & \multicolumn{2}{|l|}{ CB2 } & \multicolumn{2}{|l|}{ TPRV1 } & \multirow{2}{*}{$\begin{array}{l}\text { FABP1 } \\
\text { (liver) } \\
\text { affinity, } \\
\text { nM }\end{array}$} & \multicolumn{2}{|l|}{ GPR55 } \\
\hline & affinity, nM & efficacy & affinity, $\mathrm{nM}$ & efficacy & affinity, $\mathrm{nM}$ & efficacy & & $\begin{array}{l}\text { potency, } \\
\mathrm{nM}\end{array}$ & efficacy \\
\hline $\begin{array}{c}\text { Synthetic full agonist } \\
R-(+)-\text { WIN55212 }\end{array}$ & $\begin{array}{l}\text { Ki: } 1.89-123 \\
{[238]}\end{array}$ & $\begin{array}{l}E_{\max }: 101 \% \\
{[239]}\end{array}$ & $\begin{array}{l}\text { Ki: } 0.28-16.2 \\
{[238]}\end{array}$ & $\begin{array}{l}E_{\max }: 97 \% \\
{[239]}\end{array}$ & Ki: - & $E_{\max }:-$ & Ki: - & $\begin{array}{l}\mathrm{EC}_{50}: \\
>30,000 \\
{[239]}\end{array}$ & $E_{\max }:-$ \\
\hline \multicolumn{10}{|c|}{ Major endocannabinoids (partial agonists) } \\
\hline $\begin{array}{l}\text { AEA } \\
\text { 2-AG }\end{array}$ & $\begin{array}{l}\text { Ki: } 239.2 \\
{[240]} \\
\text { Ki: } 4.4-472 \\
{[238]}\end{array}$ & $\begin{array}{l}E_{\max }: 66 \% \\
{[239]} \\
E_{\max }: 92 \% \\
{[239]}\end{array}$ & $\begin{array}{l}\text { Ki: } 439.5 \\
{[240]} \\
\text { Ki: } 11.2-1,400 \\
{[238]}\end{array}$ & $\begin{array}{l}E_{\max }: 58 \% \\
{[239]} \\
E_{\max }: 87 \% \\
{[239]}\end{array}$ & $\begin{array}{l}\text { Ki: 1,660-2,504 } \\
{[241]} \\
\text { Ki: - }\end{array}$ & $\begin{array}{l}E_{\max }: 100 \% \\
{[242]} \\
E_{\max }:-\end{array}$ & $\begin{array}{l}\text { Ki: } 111 \\
{[243]} \\
\text { Ki: } 61 \\
{[243]}\end{array}$ & $\begin{array}{l}\mathrm{EC}_{50}: 18 \\
{[239]} \\
\mathrm{EC}_{50}: 3 \\
{[239]}\end{array}$ & $\begin{array}{l}E_{\text {max }}: 73 \% \\
{[239]} \\
E_{\text {max }}: 99 \% \\
{[239]}\end{array}$ \\
\hline \multicolumn{10}{|c|}{ Major phytocannabinoids (agonists/inverse agonists/antagonists) } \\
\hline \multicolumn{10}{|c|}{ Synthetic inverse agonist } \\
\hline Rimonabant & $\begin{array}{l}\text { Ki: } 1.8-12.3 \\
{[238]}\end{array}$ & $\begin{array}{l}E_{\max }:-48 \% \\
{[246]}\end{array}$ & $\begin{array}{l}\text { Ki: } 514-13,200 \\
{[238]}\end{array}$ & $\begin{array}{l}E_{\max }:-17 \\
{[245]}\end{array}$ & Ki: - & $E_{\text {max }}:-$ & $\begin{array}{l}\text { Ki: } 2,000 \\
{[243]}\end{array}$ & $\mathrm{EC}_{50}:-$ & $\begin{array}{l}E_{\max }: \\
\text { antagonist } \\
{[239]}\end{array}$ \\
\hline
\end{tabular}

These data were taken irrespective of tissue location. For this paper, the efficacy of CBD at TPRV1 was calculated from the available data as a percent relative to capsaicin, an exogenous molecule that has been found to activate this receptor at comparable affinity and efficacy to the endogenous ligand, AEA.

degradation and metabolism of endocannabinoids adding further complexity to this system [27].

In addition to the endocannabinoids, there are two other sources of cannabinoids comprising the phytocannabinoids (produced by members of the plant genus Cannabis) and the synthetic cannabinoids (compounds generated in the laboratory that can interact with cannabinoid receptors). Regarding the phytocannabinoids, the two most abundant and well-studied are $\Delta^{9}$-tetrahydrocannabinol $\left(\Delta^{9}-\mathrm{THC}\right)$ and cannabidiol (CBD).

There are a number of excellent reviews that describe the endocannabinoid system (ligands and receptors) as well as the phytocannabinoids from Cannabis sp. [2831]. So, rather than reviewing that information here, we will focus our attention on the medical conditions, disorders, and diseases for which cannabis has potential to be of therapeutic use. Furthermore, the enzymes that degrade the endocannabinoids, such as fatty acid amide hydrolase (FAAH) and monoacylgycerol lipase (MAGL), are also important targets for the development of novel therapeutics [32-34].

\section{Cannabis/Phytocannabinoids}

While Cannabis has been used medicinally for millennia, there has been a renewed pharmacotherapeutic interest in cannabis and phytocannabinoids following the discovery of the endogenous receptors and the role of this system in the human body [35-38]. All phytocannabinoids arise from the central precursor cannabigerolic acid (CBGA), and the highest concentrations of these compounds are primarily found within the flower portion of the female part of the plant $[14,39,40]$. In most cultivars of Cannabis, the two most common cannabinoids are THC and CBD, although over 100 cannabinoids are produced by the plant $[40,41]$. The biological properties of these cannabinoids vary greatly; for example, $\Delta^{9}$-THC has been shown to have appetite stimulating and antinausea effects, while CBD has been shown to reduce seizures and have anti-inflammatory properties [41-43]. Other major classes of compounds (e.g., flavonoids, stillbenoids, alkaloids, lignans, and terpenoids) are thought to provide synergism with phytocannabinoids in what has been termed 
an "entourage effect"; however, the mechanism of this synergism is not understood, and the existence of the "entourage effect" remains controversial [44-46].

\section{Medical Cannabis: Extracts and Routes of Administration}

Individual countries and selected states within the USA have legalized cannabis or C. sativa extracts for medical use, and several have also legalized recreational use. Medicinal cannabinoids may be administered in a variety of forms: smokable, oral (tablet), oral (edibles containing cannabis extract), oral (oils), oromucosal (oil/lozenge), vaporizable, sublingual, rectal, transcutaneous, and intravenous $[47,48]$. The most popular method, inhalation of combusted plant material (smoking), provides patients with a fast onset of action, the ability to self-titrate doses, and a much higher peak serum concentration relative to most of the other routes of administration. However, this peak quickly drops, and smoking is associated with impairment and abuse potential [47]. Additionally, due to the adverse effects that are associated with smoking, variability in individual smoking dynamics, and the variability in cannabinoid composition within different Cannabis cultivars, smoking cannabis material is not a favorable route of administration for therapeutic applications [47, 49].

The oral route of administration overcomes many of the drawbacks of inhalation; tablets contain either purified extracts or synthesized molecules of known dosage, and serum concentrations remain relatively stable [47]. The dosing of orally administered cannabinoids is complicated by their extensive first-pass metabolism in the liver (approaching 95\%) [47]. Therefore, other routes of administration that avoid this metabolism have been explored. In particular, oromucosal sprays, such as used for Sativex, allows for consistent, titratable dosing [50]. The above-described delivery methods are the two most widely utilized; however, other methods of cannabinoid delivery have been developed and have recently been reviewed by Bruni et al. [51]. In general, legal jurisdictions have either legalized the use of the intact plant materials (smoked or rendered edible) or provide for formulations of extracted cannabinoids/terpenoids (generally through supercritical $\mathrm{CO}_{2}$ or organic solvent extraction) [52-54].

\section{Medically Approved Cannabinoid Drugs}

Given the function of the endocannabinoid system, there is intense interest in the use of exogenous cannabinoid drugs for the treatment or management of a large number of disparate diseases and disorders. However, despite the number of governments that permit whole-plant consumption for medical use, only a few cannabinoid drugs have been rigorously tested for safety, efficacy, and therefore approved for use at the national level by regulatory agencies, such as the Federal Drug Administration (FDA) and the European Medicines Agency (EMA).

\section{Dronabinol (Marinol $\left.{ }^{\circledR}\right)$}

Dronabinol (trade name Marinol ${ }^{\circledR}$ ) is an orally administered and synthetically produced $\Delta^{9}$-tetrahydrocannabinol $\left(\Delta^{9}\right.$-THC) $[55,56]$. It was approved by the FDA in 1985 [57] for the treatment of anorexia and weight loss in patients with AIDS and for chemotherapy-induced nausea and vomiting (CINV) and is also approved by the EMA. This drug is classified as a schedule III substance, and the most frequently reported side effects include heart palpitations, asthenia, abdominal pain, and amnesia. A rare, but serious, side effect is depersonalization [57].

\section{Nabilone (Cesamet ${ }^{T M}$ )}

Nabilone (trade name Cesamet ${ }^{\mathrm{TM}}$ ) is an orally administered synthetic cannabinoid (structurally similar to $\Delta^{9}$ THC, see Fig. 2) with similar CB1 receptor properties as $\Delta^{9}$-THC [58]. This compound has been approved for the treatment of CINV by the FDA (in 1985, and again in 2016) and is also approved by the EMA. Due to its psychoactivity, nabilone is classified as a schedule II drug. The most frequently reported side effects are relatively minor and include orthostatic hypotension, dry mouth, drowsiness/vertigo, euphoria, dyspnea, and headache. Rare, but serious, side effects include psychosis [59].

\section{Rimonabant (Acomplia ${ }^{\circledR}$ )}

Rimonabant (trade name Acomplia ${ }^{\circledR}$ ) is a potent synthetic CB1 receptor antagonist that was marketed in Europe (from 2006 to 2009) for the management of weight, dyslipidemia, and type II diabetes [60]. However, due to serious side effects, such as major depression, suicidal ideation, nausea, and upper respiratory tract infections, this drug was withdrawn from the market by the European Medicines Agency in 2009 [61, 62].

\section{Nabiximols (Sativex ${ }^{\circledR}$ )}

Sativex is an oromucosal spray of $C$. sativa plant extract that predominantly contains $\Delta^{9}$-THC and CBD in near-equal amounts [63]. Sativex has been approved in Europe (in 2010) for the treatment of spasticity, and the most commonly reported side effects include dizziness, 
<smiles>CCCCCc1cc(O)c2c(c1)OC(C)(C)C1CCC(C)=CC21</smiles>

$\Delta^{9}-\mathrm{THC} /$ dronabinol/Marinol $^{\circledR} /$ Syndros $^{\circledR}$<smiles>C=C(C)C1CCC(C)=CC1c1c(O)cc(CCCCC)cc1O</smiles>

CBD/Epidiolex ${ }^{\oplus}$<smiles>CCCCC/C=C\C/C=C\C/C=C\C/C=C\CCCC(=O)NCCO</smiles>

Anandamide (arachidonoylethanolamine, AEA)<smiles>CCCCCCC(C)(C)c1cc(O)c2c(c1)OC(C)(C)C1CCC(=O)CC21</smiles>

nabilone/Cesamet ${ }^{\mathrm{TM}}$<smiles>Cc1c(C(=O)NN2CCCCC2)nn(-c2ccc(Cl)cc2Cl)c1-c1ccc(Cl)cc1</smiles>

SR14116A/rimonabant/Acomplia ${ }^{\circledR}$<smiles>CCCCC/C=C\C/C=C\C/C=C\C/C=C\CCCC(=O)OC(CO)CO</smiles>

2-Arachidonoylglycerol (2-AG)
Fig. 2. Cannabinoid structures. Comparison of the structures for $\Delta 9$-THC, marketed under the prescription name dronabinol (trade name Marinol and Syndros), along with the prescription medication nabilone (trade name Cesamet), a $\Delta 9$-THC derivative. Other structures included cannabidiol, the active compound in the prescription Epidiolex, and the formerly approved cannabinoid receptor antagonist SR14116A (rimonabant/Acomplia). The bottom two structures are for the endogenous cannabinoids anandamide and 2-arachidonoylglycerol. Despite the lack of structural similarity, all of these compounds interact with cannabinoid receptors. 
fatigue, blurred vision, vertigo, constipation, either appetite decrease or increase, and depression [63, 64]. Rare, but serious side effects, include palpitations, changes in blood pressure, and hallucinations [63]. Each spray contains approximately an equal ratio of CBD and $\Delta^{9}$-THC (combined for $5 \mathrm{mg}$ total).

\section{Cannabidiol (Epidiolex ${ }^{\circledR}$ )}

Cannabidiol (Epidiolex ${ }^{\circledR}$ ) is a $98 \%$ pure plant-derived oral CBD solution [65]. It has been subject to extensive toxicology studies and is approved for the treatment of seizures associated with Lennox-Gastaut syndrome or Dravet syndrome in pediatric patients [65]. Epidiolex received FDA approval in 2018 [66] and is also approved by the EMA. As a highly purified preparation of CBD, this drug may be the closest analog to $\mathrm{CBD}$ oil when investigating the potential safety and therapeutic benefit of the latter agent. Side effects include hepatocellular toxicity, decreased appetite, diarrhea, drowsiness, and fatigue [66].

\section{Cannabinoids and Disease}

A detailed discussion of the endocannabinoid system and its potential utility in pharmacotherapy was presented in 2006; however, a plethora of new data have become available in recent years [21,67]. Indeed, there are currently many ongoing clinical trials of $\Delta^{9}$-THC, CBD, and other cannabinoids reported on the FDA ClinicalTrials. gov website. As of this writing, a search for CBD yielded 352 trials (including NCT04192370, NCT04729179, NCT04731116, and NCT04978428) and a similar search for $\Delta^{9}$-THC found 322 trials (including NCT02792257, NCT03766269, NCT03560934, and NCT04734080). A review of the identified studies suggests novel avenues for the treatment of, or at least symptomatic control for, various disease states. For many diseases, there is growing evidence that suggests clinical potential for $\Delta^{9}$-THC and/ or CBD; however, there are few evidence-based, placebocontrolled studies for smokable and/or edible cannabis.

\section{Chronic Pain}

One therapeutic area for which medical cannabinoids may have the greatest potential is relieving chronic pain. The efficacy of cannabinoid treatments for neuropathy (nerve damage that results from disease, genetics, inflammation, or toxins) was assessed in a recent meta-analysis of eleven randomized controlled trials that used dronabinol (2.5-10 mg/day), nabilone (1-4 mg/day), and self-ti- trated Sativex-proportioned nabiximols (averaging 22.4 mg:20.8 mg $\Delta^{9}$-THC:CBD/day). This meta-analysis found that selected cannabinoids elicit a significant reduction in pain in patients with neuropathy [68-70]. Nabilone was found to be the most effective treatment, while nabiximols were close behind in efficacy [70]. $\Delta^{9}$ THC (dronabinol) by itself has been found to be ineffective for the treatment of neuropathic pain. However, emerging data may suggest a synergism between $\Delta^{9}$-THC and opioid medications [70]. Interestingly, another key finding was that cannabinoid-induced pain reduction is greater in patients with peripheral neuropathic pain than it is in patients with centrally arising neuropathic pain [70]. A double-blind study found that smoked cannabis provided significant analgesia relative to a placebo in patients with HIV-induced neuropathic pain [71]. Beyond pain, a majority of the analyzed trials showed improvement in each of these side measures: quality of life, sleep, anxiety, and sensory profiles [70].

In chronic or intractable pain of non-neuropathic origin, a relatively prevalent condition that is frequently treated with opioids, nabilone was found to be ineffective for the alleviation of radiotherapy-induced pain and other quality of life measures in a double-blind study of cancer patients $[72,73]$. On balance, a number of studies point to the utility of the synthetic nabilone [74-78]. Overall, trials using either Sativex or high CBD nabiximols for chemotherapy-induced pain produced nonsignificant, highly variable results [72]. Unfortunately, while these studies suggest that cannabis may have therapeutic potential, studies of nabilone will not be generalizable to phytocannabinoid mixtures.

\section{Diseases of the Central Nervous System}

Multiple Sclerosis

It is a progressive demyelinating disease $[79,80]$. Patients with MS have been found to have changes in the expression of $\mathrm{CB} 1$ and $\mathrm{CB} 2$ receptors, and this may account for therapeutic potential of cannabis-derived products [81]. Sativex is approved in several countries for the treatment of spasticity associated with MS [82]. Additionally, $\Delta^{9}$-THC alone was found to be ineffective in the management of this condition by the multi-year CUPID study [83]. Beyond spasticity, nabiximols treatment has also been found to be effective in alleviating multiple sclerosis-induced pain in multiple studies [84-86].

\section{Epilepsy}

A chronic condition of recurrent seizures often presents in childhood and arises out of abnormal excitation- 
inhibition balance of neurons in the brain [87]. Cannabinoids may act as neuroprotective agents and may also reduce inflammatory responses in patients with epilepsy $[88,89]$. Clinically, cannabidiol seems to have greater efficacy than whole-plant cannabis for the treatment of epileptic seizures as case reports and surveys have described smoked cannabis as having both pro- and anti-convulsant properties [90]. However, in regard to CBD itself, two recent open-label studies of similar design (i.e., patients with treatment-resistant epilepsy received doses of oral CBD for 3 months as an adjunctive therapy to their current anti-epileptic medications) found similar results: a responder rate of about $50 \%$ and a reduction in weekly seizure frequency of a little under 50\% [91, 92]. Despite great variation between individuals within each study, these results were mirrored in patients with different root causes of their seizures, such as Dravet syndrome and tuberous sclerosis complex [91-93]. Interestingly, cannabidiol seems to be synergistic with clobazam, and individuals with baseline cognitive and behavioral problems showed improvement in these areas, in a seizure reduction independent manner, as well [91, 92]. Additionally, other trials that used lower doses of CBD or shorter lengths of time for treatment have had mixed results [90]. In 2018, CBD (branded as Epidiolex) received FDA approval for treatment of selected intractable seizure disorders in children, approval by the EMA followed in 2019 .

\section{Amyotrophic Lateral sclerosis}

It is a progressive neurodegenerative disease of upper and lower motor neurons [94]. CB2 has been found to be upregulated following postmortem examination of patients with ALS, primarily within the spinal cord and motor cortex. This, in conjunction with the anti-inflammatory and neuroprotective aspects of cannabinoids, makes them an appealing potential therapeutic for treating ALS $[81,95]$. Experimental data have shown slight improvements in disease progression in mouse models of ALS with nabiximols treatment [82]. A double-blind crossover trial that provided $\Delta^{9}$-THC to 27 patients with ALS found no significant improvement [96]. A recent systematic review found no change in cramp intensity/frequency for ALS patients following medical cannabis [43]. Another recent clinical case study found that an oral capsule containing equal parts $\Delta^{9}$-THC and CBD reduced pruritus in a patient with ALS; however, other symptoms of the disease were not reduced [97]. A recent phase II study evaluating the efficacy of nabiximols for the treatment of spasticity in ALS patients found an improvement in spasticity in patients [98]. Yet, despite the lack of strong clin- ical study data, survey data show a patient preference for medicinal C. sativa over prescription medication due to subjective improvement in their symptoms [82].

\section{Parkinson's Disease}

It is a progressive neurodegenerative disease of the substantia nigra pars compacta dopaminergic neurons [99]. Cannabinoids have been shown to act through CB1 to regulate dopamine, and other neurotransmitters, at basal ganglia which may provide therapeutic benefit to patients with Parkinson's disease [100]. The clinical trials that have been performed have primarily investigated the efficacy of cannabinoids in limiting dyskinetic side effects of current therapies: 1 study, that tested nabilone, found a significant improvement in levodopa-induced dyskinesia while another, that tested a $2: 1-\Delta^{9}$-THC:CBD ratio of nabiximols, failed to show an effect [101, 102]. A recent phase II trial found that nabilone was able to reduce troublesome nonmotor symptoms, such as olfactory loss, mood disorders, and cognition, in patients with PD [103]. Looking at the management of the disease itself, a doubleblind study investigated the effects of pure nonpsychoactive CBD and found significant improvement in both intervention groups over the placebo in the activities of daily living and stigma categories on the Parkinson's Disease Questionnaire 39 (PDQ-39) [104]. Despite these individual findings, a recent systematic review found insufficient evidence for the use of cannabis to treat the motor symptoms associated with PD [100]. Additionally, animal models have shown cannabinoids to have antidyskinetic effects that are likely due to modulation of both the cannabinoid and TRPV receptors [105].

\section{Huntington's Disease}

It is a neurodegenerative disorder that is caused by the autosomal dominant inheritance of a mutated huntingtin (HTT) gene [106, 107]. An analysis of gene expression found a strong link between Huntington's disease and endocannabinoid system dysregulation: a mutated HTT gene is associated with the downregulation of CB1 and GPRR55 receptors and the endocannabinoid synthesizing NAPE-PLD enzyme, as well as the upregulation of the endocannabinoid degrading FAAH enzyme [108]. Clinically, neither nabiximols treatment nor CBD alone had any effect on symptom control in patients with Huntington's disease who were enrolled in double-blind studies $[109,110]$. Furthermore, nabiximol treatment was found to raise peripheral CB2 receptor expression; however, it has no effect on the expression of other endocannabinoid system proteins [110]. In contrast to the nabiximols, a 
double-blind trial, using nabilone, found this drug to be efficacious in reducing the involuntary movements associated with Huntington's disease, as well as the behavior and neuropsychiatric outcomes [111].

A small double-blind crossover study involving spinal cord injury found that nabilone treatment significantly improved spinal cord injury spasticity relative to placebo [112]. Another study has shown that nabilone significantly relieves spasticity-related pain, although this study did not find a significant decrease in spasticity [113]. In addition, other studies have shown variable results for nabilone in pain/spasticity $[114,115]$.

\section{Post-traumatic Stress Disorder}

Post-traumatic stress disorder is rooted in extreme emotional events [116]. Survey and cross-sectional data have shown that cannabis use can improve global PTSD symptoms, as well as providing a correlation between reduced PTSD severity and cannabis use [117]. These data are supported by a double-blind study of active-duty Canadian military personnel, for whom standard treatment was ineffective, in which nighttime doses of nabilone had a significant and beneficial effect on PTSD-related nightmare frequency [118]. Cannabinoids have also been found to be effective for reducing the anxiety, but not the depression that is associated with PTSD, as well as multiple other disorders [42].

\section{Anxiety}

One of the most common reported reasons patients take cannabis is to treat anxiety, and this is especially true for products high in CBD $[119,120]$. A recent work has found a role for the endocannabinoid system in modulating mood, and, as such, cannabinoids may be of therapeutic benefit to reducing anxiety [121]. Preclinical models in mice have found that the cannabinoid agonist WIN 55,212 is able to reduce anxiety-like responses $[122,123]$. Similar findings were also observed with an inhibitor of anandamide hydrolase, which leads to an increase in anandamide levels [122]. A double-blind, randomly controlled trial of 24 social anxiety disorder patients found that CBD at a dose of $600 \mathrm{mg}$ when given $1.5 \mathrm{~h}$ before public speaking was able to significantly reduce anxiety when compared to healthy controls [124]. A search of Clinicaltrials.gov shows there are currently eight clinical trials underway to investigate the potential of $\mathrm{CBD}$ as an anxiety medication. Nabilone has also been shown to reduce anxiety in a small, placebo-controlled crossover study [125]. Importantly, $\Delta^{9}$-THC has been shown to increase anxiety-like behavior in mice and rats $[126,127]$.
In a recent systematic review of twelve studies looking at anxiety onset, three found that cannabis use increased the odds of developing anxiety disorders [128]. Reports also indicate that high $\Delta^{9}$-THC cannabis is more likely to induce anxiety symptoms in naïve patients $[129,130]$. So, while some cannabinoids may have therapeutic utility in reducing anxiety, caution should be exercised regarding $\Delta^{9}$-THC because the association between $\Delta^{9}$-THC and anxiety is still unclear.

\section{Sleep}

A common reason that individuals report using $\mathrm{CBD}$ oil is to help with sleep $[131,132]$. However, there are currently few to no clinical data in humans that support the use of CBD for sleep. Studies in rats suggest that there is a correlation between CBD dose and increased percentage of sleep [133-135]. Additionally, chronic CBD exposure in adolescent rats leads to a decrease in wakefulness during the dark period [136]. Survey data from people using CBD to promote sleep have been highly variable, and this may be attributed to the high variability in the content and quality of CBD currently on the market [132]. In contrast, acute $\Delta^{9}$-THC use is associated with increased total sleep time, while chronic $\Delta^{9}$-THC use may lead to sleep disruption (possibly due to tolerance) [137]. Interestingly, withdrawal from $\Delta^{9}$-THC is associated with an increase in vivid dreams and sleep disturbance [137]. Taken together, as with most diseases, more data are needed to make any conclusion on the benefit of cannabinoids for promoting sleep.

\section{Opioid Use Disorder}

The opioid crisis in North America has been one of the most pressing health issues of our time and continues to grow. Cannabis has been proposed to augment medication-assisted treatments such as methadone and buprenorphine. In particular, the noneuphorigenic cannabinoid CBD is viewed as having potential therapeutic use for the treatment of opioid use disorder (OUD); unfortunately, to date, only short pilot studies have been conducted, and therefore the effectiveness of this treatment remains unclear [138]. However, another recent study found that daily cannabis use was associated with lower opioid use during treatment of OUD [139]. These findings are in agreement with another study that found cannabis users show lower symptoms of withdrawal [140]. Epidiolex has recently been found to reduce cravings and anxiety in heroin-abstinent individuals [141]. Clearly, cannabis will not serve as an effective replacement for OUD individuals, but it may serve as a valuable addition 
to traditional medication-assisted treatments (methadone, buprenorphine, and naltrexone) [141, 142]. Of course, substitution of one abused substance with another will not be well received by some healthcare providers.

\section{Tourette's Syndrome}

Tourette's syndrome is a neuropsychiatric disorder associated with verbal and physical tics. Additionally, many patients also suffer from comorbidities such as attention deficit/hyperactivity disorder, obsessive-compulsive behavior/disorder, anxiety, depression, and rage attacks [143]. Because of the anti-anxiety potential of cannabinoids and the high level of receptor expression in the striatum, cannabis may be a therapeutic for Tourette's [144]. To date, only two small, controlled trials have been conducted using dronabinol, and both studies found that dronabinol was able to reduce the number of tics with few adverse effects $[145,146]$. There is currently a larger multicenter clinical trial being conducted to evaluate the effectiveness of nabiximols for the treatment of Tourette's syndrome, and data from this study will be highly valuable for validating the findings of the two smaller trials previously conducted [147].

\section{Cancer and Cancer-Related Illness}

Two major factors that diminish the quality of life in cancer patients are CINV and cancer cachexia, which is a state of weight and muscle loss that results from metabolic changes, chemotherapy, and inflammation [148, 149]. One aspect of cannabinoid signaling includes the establishment of an anti-emesis tone through the inhibition of serotonin signaling in the brainstem [150, 151]. Treatment with either dronabinol or nabiximols has been shown to be similarly efficacious for the treatment of CINV [42]. Data suggest that cannabinoid treatment may be superior to the anti-emetic drugs that are currently on the market [42]. Interestingly, nausea and vomiting that are induced by other factors, such as surgery, are not reduced by $\Delta^{9}$-THC [152]. In regard to cancer cachexia, dronabinol treatment may increase appetite; however, its effect is inferior to other available treatments [153]. The lack of significance in these trials may be, in part, explained by the relatively low doses administered since smoked high-THC cannabis has been shown to increase caloric intake in healthy individuals [153]. A meta-anal$y$ sis of four studies investigating the effects of dronabinol on weight gain in HIV-infected individuals found a mix of significant and nonsignificant increases in weight and appetite in these patients [42].
In addition to reducing nausea and increasing appetite in cancer patients, a number of cannabinoids have been identified that reduce cancer cell growth in vitro. These studies will be described in detailed in the following sections.

\section{Gliomas and Glioblastomas}

They are a group of highly invasive primary malignancies of the brain [154]. In regard to medicinal cannabinoids, there are very little clinical data on their utility. However, cell and animal studies, along with limited human trials, suggest that $\Delta^{9}$-THC (perhaps modulated by CBD) may lower tumor vascularization, promote cell death, and limit metastasis [155-157].

\section{Colorectal Cancer}

It despite being easily treated by resection is highly heterogeneous and therefore at risk for drug resistance because of frequent epigenetic changes [158, 159]. Clinical data regarding treatment of this disease with cannabinoids also remain minimal; however, a significant association between increases in CB1 receptor expression in colorectal cancer samples, cancer stage, and prognosis has been observed [160-162]. Interestingly, cannabinoids may act synergistically, in a cannabinoid receptor-independent manner, with chemotherapeutics, such as 5-fluorouracil, in eliciting their antiproliferative action on colorectal cancers [163]. Our own recent findings suggest that cannabinoids may reduce colorectal cancer cell viability through a mechanism independent of CB1, CB2, GPR55, and TRPV1 [164].

\section{Pancreatic, Lung, and Breast Cancers}

They are leading causes of cancer-related death in the world [165]. Investigations have shown that synthetic cannabinoids inhibit pancreatic cancer growth through the promotion of autophagy [166]. Similar to colorectal cancer, however, CB1 receptor overexpression is associated with shorter survival [167]. Symptomatically, the deterioration of pancreatic cancer patient quality of life is largely due to pain, anxiety, sleep disturbance, and cachexia that may be mitigated by cannabinoids $[42,168]$. Cannabinoid treatment for lung cancer is still in the preclinical stage; however, data from these experiments suggest a proapoptotic potential for CBD on cells from a primary lung tumor while increased AEA levels, achieved through FAAH inhibition, have been shown to inhibit EFGR signaling and induce apoptosis [169]. Breast cancer remains the primary cause of cancer-related death for women around the world $[170,171]$. Modern treatment options, 
which include chemotherapy, radiotherapy, and surgery, still diminish quality of life due to their adverse side effects [171]. As discussed with pancreatic cancer, cannabinoid treatment seems to help limit sleep disturbances and pain [42]. Therefore, medicinal cannabinoids may be used in conjunction with classical chemotherapeutics for the reduction of their side effects. Meanwhile, breast cancer is unlike pancreatic and colorectal cancers in that it is associated with increased levels of the $\mathrm{CB} 2$ receptor, rather than the $\mathrm{CB} 1$ receptor, and overexpressed levels of FAAH [169]. This may help to explain why multiple preclinical models of this cancer have shown that cannabidiol, an inverse agonist/antagonist at the $\mathrm{CB} 2$ receptor and an FAAH inhibitor, is effective at reducing breast cancer proliferation, invasion, and metastasis [172-174] (Table 1).

\section{Glaucoma}

Glaucoma involves the degeneration of retinal ganglion cells, increased intraocular pressure (IOP), and eventual blindness [175]. Clinically, medicinal cannabinoids have been found to reduce IOP: a sublingual dose of $5 \mathrm{mg}$ of $\Delta^{9}$-THC significantly reduced IOP in a double-blind study of glaucoma. Moreover, topical administration of the synthetic cannabinoid, WIN55212-2 (a CB1/CB2 agonist), at doses of 25-50 $\mu \mathrm{g}$, had a similar effect $[176,177]$. Intravenous $\Delta^{9}$-THC, $\Delta^{8}$-THC, and 11-hydroxyl- $\Delta^{9}$ THC, as well as oral nabilone, have also been found to effectively decrease IOP [178]. Yet, despite these encouraging findings, there is no evidence that cannabinoid treatments slow the progression of this disease [178]. Additionally, as the hypotensive effects of these treatments average only 3-4 h, compliance with repeated administration and cost are other concerns [178].

\section{Inflammatory Bowel Disease}

A wealth of survey data suggest that individuals with inflammatory bowel disease use these substances to medicate their symptoms [179]. Indeed, a recent review and a retrospective cohort study suggest that many IBD patients report the use of high-THC cannabis to specifically manage the pain associated with this medical condition $[180,181]$. These survey data are supported by doubleblind clinical data. A study provided steroid and immunomodulator nonresponsive patients with smoked $\Delta^{9}$ THC twice a day and found a significant reduction in Crohn's Disease Activity Index scores [182]. These patients also had improvements in sleep and appetite, and about one-third of the patients in the intervention group were weaned off of steroid treatment [182]. Unfortunately, despite the symptomatic relief that cannabinoids pro- vide, their prolonged use is strongly associated with a worse prognosis and the need for surgical treatment [183]. An examination of the US government's clinical trials website (https://clinicaltrials.gov) reveals that there are a number of ongoing trials of nabiximols for the treatment of inflammatory bowel disease.

\section{Summary}

While there are pharmacological reasons to believe that cannabinoids may have beneficial effects, there is insufficient clinical trial evidence to make definitive statements. Certainly, pure $\Delta^{9}$-THC has been documented to be efficacious in appetite stimulation, treatment of nausea and vomiting, and amelioration of spasticity in multiple sclerosis, and CBD has been found to be effective for the treatment of pediatric seizure disorders. Major impediments to studying cannabis, cannabis extracts, and CBD oil are (1) the federal regulations of high-THC cannabis in the USA and (2) the lack of motivation on the part of major pharmaceutical companies to invest in clinical trials that will not produce a patent-protected prescription drug. In this regard, ongoing clinical trials on Cannabis extracts containing $\Delta^{9}$-THC/CBD (and other cannabinoids, terpenoids, and phytochemicals; nabiximols) may serve as a surrogate marker for Cannabis in general.

\section{Adverse Effects of Cannabinoids}

According to the US Substance Abuse and Mental Health Services Administration, the proportion of developing adolescents (ages 12-17) in the USA who are current high-THC cannabis users has remained the same (at 7.4\%) over the last decade [184]. However, this same study also notes a recent uptick in the use of this substance among older individuals. Therefore, if the connection between parental drinking and adolescent drinking holds true for other substances of abuse, this uptick may foreshadow later increases in illicit marijuana consumption among this particularly vulnerable population [185]. This is especially worrying as emerging evidence indicates serious contraindications for heavy cannabis use by adolescents [186]. Moreover, there is growing concern for the emergence of cannabis-induced hyperemesis syndrome, or uncontrolled vomiting, observed in both adolescents and adults $[187,188]$. A further complication is the fact that there seems to have been a marketplace race (in jurisdictions with legalized recreational cannabis) to provide products with higher and higher $\Delta^{9}$-THC levels and with lower and lower CBD $[189,190]$. 


\section{Adverse Effects on Cognition and Development}

As described above, endocannabinoids have an important role in tempering neuronal excitability through modulation of the release of the GABA and glutamate neurotransmitters. The disruption of these processes, such as through exposure to high doses of exogenous cannabinoids prior to the age of sixteen, has been implicated in the arrest of cortical maturation due to the dysregulation of nerve connection potentiation and brain plasticity $[191,192]$. When paired with research that links reduced mitochondrial activity with cannabis use and poor memory formation, these data serve to explain the drop of $\sim 2$ 6 IQ points that has been observed from childhood to adulthood in persistent cannabis users [193, 194]. Notably, this drop in neuropsychological function is not fully reversed with cessation of the drug, and this was observed even when years of education, alcohol use, and other drug dependences were considered [193]. More acutely, in regard to memory, intravenous $\Delta^{9}$-THC administration in the amount of $0.03 \mathrm{mg} / \mathrm{kg}$, or about $2.4 \mathrm{mg}$ for the average North American, inhibits the encoding of verbal information and significantly decreases immediate and delayed recall in a broad spectrum of ages $[195,196]$. This dose is also sufficient for the development of cannabis euphoria, anxiety, impaired cognition, and schizophrenia-like symptoms that are associated with this drug [197]. In addition to IQ scores and memory, the effects of cannabis use on cognition have also been found to manifest themselves in a sex-dependent manner that is exacerbated by an earlier age of use: females seem to primarily exhibit decreases in episodic memory, while male subjects show poorer decision-making skills [198, 199].

\section{Psychological Risk}

Adolescent cannabis use has been associated with increased rates of psychological disorders. The age at which an individual first uses cannabis has been shown to have a significant correlation with the frequency and severity of lifetime manic, anxiety, and obsessive-compulsive symptoms [200]. This is especially true in what has been described as a "vulnerable minority" of early users who are genetically predisposed to cannabis-induced psychological harm - an effect that is seen even when controlling for symptoms before cannabis use [201]. Growing evidence suggests that normal genetic variation in a variety of different genes is serving to interact with cannabinoids to create behavioral problems, dependence, and increased impulsivity [202-205]. While correlation does not equal causation, and it may be possible that individuals with underlying psychoses are predisposed to use Cannabis, it has been hypothesized that individuals with these alterations may use these substances to self-medicate subthreshold symptoms and that this use then worsens their condition in a perpetuating cycle [203]. Mechanistically, another route by which these psychological disorders may be instigated by chronic cannabis use is through the upregulation of $5-\mathrm{HT}_{2 \mathrm{~A}}$ serotonin receptors by $\mathrm{CB} 2$ receptor activation [206].

Exposure to cannabis, $\Delta^{9}$-THC, or other euphorigenic cannabinoids has been shown to induce psychotic symptoms in a high percentage (20-50\%) of the population [207, 208]. These symptoms manifest as both positive (suspiciousness, grandiose delusions, fragmented thinking, etc.) and negative (emotional withdrawal, psychomotor retardation, blunted affect, etc.) and are observed shortly after exposure $[207,209,210]$. The addition of the noneuphorigenic cannabinoids, such as CBD, may blunt these psychotic symptoms, although the findings are highly variable between studies [210]. While these symptoms are generally transient and are resolved after the period of intoxication, there is a subset of individuals in which the symptoms persist after intoxication has ended. This is known as cannabisinduced acute persistent psychosis (CIAPP). Symptoms of CIAPP include hallucinations, amnesia, disorientation, paranoia, and depersonalization [207, 208]. While this psychosis persists after the initial intoxicating event, CIAPP resolves faster than schizophrenic episodes and does not usually reoccur unless there is a subsequent exposure to cannabis or cannabinoids [207, 208].

Another area of concern with the use of high-THC cannabis is a well-documented association between cannabis use and risk of psychosis. A meta-analysis of 10 studies identified a 4 -fold increase in risk of psychosis among heavy users and a 2-fold increase in risk among average users [211]. Similarly, another meta-analysis found a significant relationship between exacerbated mania symptoms in patients with bipolar disorder and a 3 -fold increase in mania symptoms in nonclinical patients [212]. The most common psychological illness associated with high-THC cannabis use is schizophrenia, and while this association is modest, it is also consistent across a number of studies and cohorts [207]. This link between cannabis use and schizophrenia has been demonstrated in longitudinal studies in populations from Sweden [213, 214], the Netherlands [201], Germany [215], and New Zealand [216]. Interestingly, the Swedish cohort showed that the risk for developing schizophrenia decreased as the follow-up time increased, suggesting that there is a genetic predisposition that cannabis use can exacerbate $[207,214]$. Of note, in individuals that were pre- 
viously diagnosed with CIAPP, $50 \%$ of those without a pre-existing condition were diagnosed with a schizophrenia-spectrum disorder after 8 years $[207,208] . \Delta^{9}$-THC has also been shown to worsen symptoms even in patients that are being treated and on a stable dose of antipsychotics [207]. Interestingly, CBD has been shown to have antipsychotic properties in both animal models and in selected studies in patients [217-220]. Importantly, other studies in patients failed to find consistent or marked improvements in patients suffering from schizophrenia $[221,222]$. Taken together, while CBD may reduce the psychotic activities of $\Delta^{9}$-THC, further work is needed to validate these findings.

\section{Future Imperatives}

\section{Implications for Opioid Use}

Cannabinoids have engendered interest as a tool in fighting the opioid epidemic. When cannabinoids are used in conjunction with opioid medications for the treatment of chronic pain, one study found a $64 \%$ decrease in opioid use [223]. Mechanistically, exogenous cannabinoids seem to elicit this effect through the tempering of opioid withdrawal symptoms. Moreover, as the opioid-sparing effect of cannabinoids was observed to be greater in patients with peripheral pain rather than central, the TRPV1 receptor is a possible mediator, as are common signal transduction pathways [223-225]. Exogenous cannabinoids have also been found to allosterically modulate multiple opioid receptors; this function may serve to lower the opioid dosage that is necessary to achieve their analgesic effect [226]. This idea is supported by the fact that although there is a $27 \%$ decrease in reported pain when these medications are used together, opioid plasma concentration pharmacokinetics do not significantly change after the administration of cannabinoids [227]. As a result, research should focus on the use of cannabinoids as adjunct therapies for pain management as a tool to reduce the overall use of opioids.

Difficulties Performing Research on Medical Cannabis High-THC cannabis and its derivatives are regulated, in the USA (under the Controlled Substances Act of 1970), as a schedule I controlled substance. This is a classification that defines these drugs as having a high potential for abuse, no currently accepted medical use, and a lack of accepted safety for use under medical supervision [228]. This impedes research progress through reduced access and resistance to clinical trials - not to mention societal stigmas. Further complicating the study of medical cannabis is the diverse array of phytocannabinoids found in C. sativa that may work in concert in what has been termed the "entourage effect." $\Delta^{9}$-THC and CBD, however, that contain largely different pharmacodynamics, are the most prevalent cannabinoid molecules found within C. sativa (Table 1). This has led to the development of medications that contain ratios of CBD and $\Delta^{9}$-THC that differ from those found naturally (e.g., Sativex ${ }^{\circledR}$ [nabiximols]). Interestingly, CBD to $\Delta^{9}$-THC ratios above what are found normally seem to attenuate and/or reverse the psychoactivity, euphoria, and impaired facial emotional processing that are caused by relatively higher amounts of $\Delta^{9}$-THC [229-231]. Furthermore, noncannabinoid components of the $C$. sativa plant, such as terpenoids, may also modulate the bioactivity of the cannabinoids [46, 232].

A further difficulty in studying one of the most easily accessible forms of cannabis medication, CBD oils, is that there is currently little to no regulation on the labeling of these products. In fact, studies have found that some oils contain little to no CBD and that levels of $\Delta^{9}$-THC are often higher than reported [233-235]. Additionally, we have shown that the content of the oils can alter the efficacy of the CBD in some situations, further complicating the ability to study these products [236]. While variations in terpene and cannabinoid content in oil are unavoidable due to cultivar variation and extraction methods, efforts should be made to ensure that the labels match the content, which will undoubtedly require regulation of this growing industry.

Future trials for any disease or medical condition should be performed using standardized variables for different formulations for testing efficacy and routes of administration. In a similar vein, changes in the expression of endocannabinoid system genes should also be better characterized in human subjects with these conditions to provide further insight into potential therapies. Other approaches, such as the inactivation of the FAAH and MAGL metabolic enzymes of the endocannabinoid system, are gathering much interest [237].

Finally, there is considerable disagreement between the scientific and lay communities on routes of administration. Much pressure is focused on use of combustible plant materials (with its attendant psychoactivity, potential entourage effects, and its diversion to recreational use). However, this approach prevents effective placebo studies (there is no "sham" condition as the euphoria associated with $\Delta^{9}$-THC is obvious when administered in this way) or carefully controlled dose-effect studies. As a result, double-blind, placebo-controlled trials (the gold standard for evaluating efficacy) are very difficult, if not 
impossible. Therefore, moving forward the field requires studies to evaluate carefully characterized extracts of compounds to better understand dosing, blood levels, and pharmacotherapeutic outcomes.

\section{Acknowledgments}

The authors would like to acknowledge the members of the Penn State College of Medicine Medical Marijuana Academic Clinical Research Center for discussions and support.

\section{Conflict of Interest Statement}

K.E.V. and the Penn State College of Medicine are the recipients of research support from PA Options for Wellness (a stateapproved medical marijuana clinical registrant).

\section{Funding Sources}

K.E.V. and the Penn State College of Medicine are the recipients of research support from PA Options for Wellness, a Pennsylvania-approved medical marijuana Clinical Registrant. The Penn State College of Medicine is a Pennsylvania-approved Medical Marijuana Academic Clinical Research Center. The funding source had no involvement in the writing or analysis of work presented.

\section{Author Contributions}

The manuscript was written by C.A.L. and W.M.R.K. and revised by W.M.R.K. and K.E.V.

\section{References}

1 Barthwell A, Baxter L, Cermak T, DuPont R, Kraus M, Levounis P. The role of the physician in "medical" marijuana: American Society of Addiction Medicine ASAM; 2010.

2 Kondrad E, Reid A. Colorado family physicians' attitudes toward medical marijuana. J Am Board Fam Med. 2013 Jan;26(1):52-60.

3 Russo EB, Burnett A, Hall B, Parker KK. Agonistic properties of cannabidiol at 5-HT1a receptors. Neurochem Res. 2005 Aug;30(8): 1037-43.

4 Pertwee $\mathrm{R}$. The diverse $\mathrm{CB} 1$ and $\mathrm{CB} 2$ receptor pharmacology of three plant cannabinoids: $\Delta 9$-tetrahydrocannabinol, cannabidiol and $\Delta 9$-tetrahydrocannabivarin. $\mathrm{Br} \mathrm{J}$ Pharmacol. 2008;153(2):199-215.

5 Granja AG, Carrillo-Salinas F, Pagani A, Gómez-Cañas M, Negri R, Navarrete C, et al. A cannabigerol quinone alleviates neuroinflammation in a chronic model of multiple sclerosis. J Neuroimmune Pharmacol. 2012 Dec; 7(4):1002-16

6 Rock EM, Bolognini D, Limebeer CL, Cascio MG, Anavi-Goffer S, Fletcher PJ, et al. Cannabidiol, a non-psychotropic component of cannabis, attenuates vomiting and nausealike behaviour via indirect agonism of 5-HT(1A) somatodendritic autoreceptors in the dorsal raphe nucleus. Br J Pharmacol. 2012 Apr;165(8):2620-34.

7 Devane WA, Hanus L, Breuer A, Pertwee RG, Stevenson LA, Griffin G, et al. Isolation and structure of a brain constituent that binds to the cannabinoid receptor. Science. 1992 Dec; 258(5090):1946-9.

8 Opitz CA, Rimmerman N, Zhang Y, Mead LE, Yoder MC, Ingram DA, et al. Production of the endocannabinoids anandamide and 2-arachidonoylglycerol by endothelial progenitor cells. FEBS Lett. 2007 Oct;581(25):4927-31.
9 Maccarrone M. Metabolism of the endocannabinoid anandamide: open questions after 25 years. Front Mol Neurosci. 2017;10:166.

10 De Petrocellis L, Starowicz K, Moriello AS, Vivese M, Orlando P, Di Marzo V. Regulation of transient receptor potential channels of melastatin type 8 (TRPM8): effect of cAMP, cannabinoid $\mathrm{CB}(1)$ receptors and endovanilloids. Exp Cell Res. 2007 May;313(9):1911-20.

11 Cascio MG, Gauson LA, Stevenson LA, Ross RA, Pertwee RG. Evidence that the plant cannabinoid cannabigerol is a highly potent alpha2-adrenoceptor agonist and moderately potent 5 HT1 A receptor antagonist. Br J Pharmacol. 2010 Jan;159(1):129-41.

12 De Petrocellis L, Ligresti A, Moriello AS, Allarà $\mathrm{M}$, Bisogno $\mathrm{T}$, Petrosino $\mathrm{S}$, et al. Effects of cannabinoids and cannabinoid-enriched Cannabis extracts on TRP channels and endocannabinoid metabolic enzymes. Br J Pharmacol. 2011 Aug;163(7):1479-94.

13 De Petrocellis L, Orlando P, Moriello AS, Aviello G, Stott C, Izzo AA, et al. Cannabinoid actions at TRPV channels: effects on TRPV3 and TRPV4 and their potential relevance to gastrointestinal inflammation. Acta Physiol. 2012 Feb;204(2):255-66.

14 Nachnani R, Raup-Konsavage WM, Vrana KE. The pharmacological case for cannabigerol. J Pharmacol Exp Ther. 2021 Feb;376(2): 204-12.

15 Murataeva N, Straiker A, Mackie K. Parsing the players: 2-arachidonoylglycerol synthesis and degradation in the CNS. Br J Pharmacol. 2014 Mar;171(6):1379-91.

16 Hanlon EC, Tasali E, Leproult R, Stuhr KL, Doncheck E, de Wit $\mathrm{H}$, et al. Circadian rhythm of circulating levels of the endocannabinoid 2-arachidonoylglycerol. J Clin Endocrinol Metab. 2015 Jan;100(1):220-6.
17 Bisogno T, Berrendero F, Ambrosino G, Cebeira M, Ramos JA, Fernandez-Ruiz JJ, et al. Brain regional distribution of endocannabinoids: implications for their biosynthesis and biological function. Biochem Biophys Res Commun. 1999 Mar;256(2):377-80.

18 Thabuis C, Tissot-Favre D, Bezelgues JB, Martin JC, Cruz-Hernandez C, Dionisi F, et al. Biological functions and metabolism of oleoylethanolamide. Lipids. 2008 Oct;43(10):887-94.

19 Kaczocha M, Vivieca S, Sun J, Glaser ST, Deutsch DG. Fatty acid-binding proteins transport $\mathrm{N}$-acylethanolamines to nuclear receptors and are targets of endocannabinoid transport inhibitors. J Biol Chem. 2012 Jan; 287(5):3415-24.

20 Mattace Raso G, Russo R, Calignano A, Meli R. Palmitoylethanolamide in CNS health and disease. Pharmacol Res. 2014 Aug;86:32-41.

21 Pertwee RG. Endocannabinoids and their pharmacological actions. Handb Exp Pharmacol. 2015;231:1-37.

22 Castillo PE, Younts TJ, Chávez AE, Hashimotodani Y. Endocannabinoid signaling and synaptic function. Neuron. 2012 Oct;76(1): 70-81.

23 Zou S, Kumar U. Cannabinoid receptors and the endocannabinoid system: signaling and function in the central nervous system. Int J Mol Sci. 2018 Mar;19(3):833.

24 Lowe H, Toyang N, Steele B, Bryant J, Ngwa $\mathrm{W}$. The endocannabinoid system: a potential target for the treatment of various diseases. Int J Mol Sci. 2021 Aug 31;22(17):9472.

25 Joshi N, Onaivi ES. Endocannabinoid system components: overview and tissue distribution. Adv Exp Med Biol. 2019;1162:1-12.

26 Biringer RG. Endocannabinoid signaling pathways: beyond CB1R and CB2R. J Cell Commun Signal. 2021 Sep;15(3):335-60. 
27 Di Marzo V, Piscitelli F. The endocannabinoid system and its modulation by phytocannabinoids. Neurotherapeutics. 2015 Oct; 12(4):692-8.

28 Amin MR, Ali DW. Pharmacology of medical cannabis. Adv Exp Med Biol. 2019;1162:15165.

29 Pacher P, Kogan NM, Mechoulam R. Beyond THC and Endocannabinoids. Annu Rev Pharmacol Toxicol. 2020;60:637-59.

30 Rock EM, Parker LA. Constituents of Cannabis sativa. Adv Exp Med Biol. 2021;1264:1-13.

31 Stasiłowicz A, Tomala A, Podolak I, CieleckaPiontek JL. As a natural drug meeting the criteria of a multitarget approach to treatment. Int J Mol Sci. 2021 Jan;22(2):778.

32 Bajaj S, Jain S, Vyas P, Bawa S, Vohora D. The role of endocannabinoid pathway in the neuropathology of Alzheimer's disease: can the inhibitors of MAGL and FAAH prove to be potential therapeutic targets against the cognitive impairment associated with Alzheimer's disease? Brain Res Bull. 2021 Sep;174: 305-22.

33 van Egmond N, Straub VM, van der Stelt M. Targeting endocannabinoid signaling: FAAH and MAG lipase inhibitors. Annu Rev Pharmacol Toxicol. 2021;61:441-63.

34 Wilkerson JL, Bilbrey JA, Felix JS, Makriyannis A, McMahon LR. Untapped endocannabinoid pharmacological targets: pipe dream or pipeline? Pharmacol Biochem Behav. 2021 Jul;206:173192.

35 Alexander SP. Therapeutic potential of cannabis-related drugs. Prog Neuropsychopharmacol Biol Psychiatry. 2016 Jan;64:157-66.

36 European Monitoring Centre for Drugs and Drug Addiction. Cannabis legislation in Europe: EMCDDA: European Monitoring Centre for Drugs and Drug Addiction; 2017.

37 Baron EP. Medicinal properties of cannabinoids, terpenes, and flavonoids in cannabis, and benefits in migraine, headache, and pain: an update on current evidence and cannabis science. Headache. 2018 Jul;58(7):1139-86.

38 Mouhamed Y, Vishnyakov A, Qorri B, Sambi M, Frank SS, Nowierski C, et al. Therapeutic potential of medicinal marijuana: an educational primer for health care professionals. Drug Healthc Patient Saf. 2018;10:45-66.

39 Fellermeier M, Zenk MH. Prenylation of olivetolate by a hemp transferase yields cannabigerolic acid, the precursor of tetrahydrocannabinol. FEBS Lett. 1998 May;427(2):283-

40 Andre CM, Hausman JF, Guerriero G. Cannabis sativa: the plant of the thousand and one molecules. Front Plant Sci. 2016;7:19.

41 Kumar P, Mahato DK, Kamle M, Borah R, Sharma B, Pandhi S, et al. Pharmacological properties, therapeutic potential, and legal status of Cannabis sativa L: an overview. Phytother Res. 2021 Jul 08;35(11):6010.

42 Whiting PF, Wolff RF, Deshpande S, Di Nisio M, Duffy S, Hernandez AV, et al. Cannabinoids for medical use: a systematic review and meta-analysis. JAMA. 2015;313(24):2456-73.
43 Jugl S, Okpeku A, Costales B, Morris EJ, Alipour-Haris G, Hincapie-Castillo JM, et al. A mapping literature review of medical cannabis clinical outcomes and quality of evidence in approved conditions in the USA from 2016 to 2019. Med Cannabis Cannabinoids. 2021; 4:21-42.

44 McPartland J, Russo E. Cannabis and cannabis extracts: greater than the sum of their parts. J Cannabis Therap. 2001;1(3-4):103-32.

45 Flores-Sanchez IJ, Verpoorte R. Secondary metabolism in cannabis. Phytochem Rev. 2008;7(3):615-39.

46 Russo EB. Taming THC: potential cannabis synergy and phytocannabinoid-terpenoid entourage effects. Br J Pharmacol. 2011 Aug; 163(7):1344-64.

47 Huestis MA. Human cannabinoid pharmacokinetics. Chem Biodivers. 2007 Aug; 4(8): 1770-804.

48 Crowley K, de Vries ST, Moreno-Sanz G. Selfreported effectiveness and safety of Trokie ${ }^{\infty}$ lozenges: a standardized formulation for the buccal delivery of cannabis extracts. Front Neurosci. 2018;12:564.

49 Giese MW, Lewis MA, Giese L, Smith KM. Development and validation of a reliable and robust method for the analysis of cannabinoids and terpenes in cannabis. J AOAC Int. 2015;98(6):1503-22.

50 Pharmaceuticals G. Sativex oromucosal spray: Emcemc; 2015.

51 Bruni N, Della Pepa C, Oliaro-Bosso S, Pessione E, Gastaldi D, Dosio F. Cannabinoid delivery systems for pain and inflammation treatment. Molecules. 2018 Sep;23(10):2478.

52 Varlet V, Concha-Lozano N, Berthet A, Plateel G, Favrat B, De Cesare M, et al. Drug vaping applied to cannabis: is "Cannavaping" a therapeutic alternative to marijuana? Sci Rep. 2016 May;6:25599.

53 Carliner H, Brown QL, Sarvet AL, Hasin DS Cannabis use, attitudes, and legal status in the US: a review. Prev Med. 2017 Jul;104:13.

54 Zhang W, Wang J, Mi Z, Su J, You X, Keceli $\mathrm{G}$, et al. Extraction and analysis of tetrahydrocannabinol, a cannabis compound in oral fluid. Int J Bio. 2017;9(1):30-5.

55 Dronabinol. Full prescribing information. Dronabinol $\left(\mathrm{Marinol}^{\circ}\right)$; 2018. https://www. rxabbvie.com/pdf/marinol_PI.pdf.

56 Dronabinol. Full prescribing information. Dronabinol $\left(\right.$ Syndros $\left.{ }^{\circledR}\right) ; 2018$. http://syndros. com/wp-content/uploads/2019/06/SYNDROS-label.pdf.

57 Food and Drug Administration. Marinol ${ }^{\circ}$. New drug application: Food and Drug Administration: FDA; 2004.

58 Food and Drug Administration. CesametTM. New drug application: Food and Drug Administration: FDA; 2006.

59 Food and Drug Administration. CesametTM. New drug application: Food and Drug Administration: FDA; 2006.

60 European Medicines Agency. Acomplia. European public assessment report: European Medicines Agency: EMA; 2007.
61 European Medicines Agency. Acomplia. European public assessment report: European Medicines Agency: EMA; 2006.

62 European Medicines Agency. Acomplia: European Medicines Agency: EMA; 2009.

63 Electronic Medicines Compendium. Sativex oromucosal spray: EMC; 2015.

64 European Medicines Agency. EMEA-000181PIP01-08-M03. PIP. European Medicines Agency: EMA; 2016.

65 Full Cannabidiol. Prescribing Information. Cannabidiol (Epidiolex); 2018. https://www. epidiolex.com/sites/default/files/EPIDIOLEX_Full_Prescribing_Information.pdf2018.

66 Food and Drug Administration. Epidiolex. New drug application: Food and Drug Administration: FDA; 2018.

67 Pacher P, Bátkai S, Kunos G. The endocannabinoid system as an emerging target of pharmacotherapy. Pharmacol Rev. 2006 Sep; 58(3):389-462.

68 Watson JC, Dyck PJ. Peripheral neuropathy: a practical approach to diagnosis and symptom management. Mayo Clin Proc. 2015 Jul; 90(7):940-51.

69 Rajabally YA, Adams D, Latour P, Attarian S. Hereditary and inflammatory neuropathies: a review of reported associations, mimics and misdiagnoses. J Neurol Neurosurg Psychiatry. 2016 Oct; 87(10):1051-60.

70 Meng H, Johnston B, Englesakis M, Moulin DE, Bhatia A. Selective cannabinoids for chronic neuropathic pain: a systematic review and meta-analysis. Anesth Analg. 2017 May; 125(5): 1638 .

71 Ellis RJ, Toperoff W, Vaida F, van den Brande G, Gonzales J, Gouaux B, et al. Smoked medicinal cannabis for neuropathic pain in HIV: a randomized, crossover clinical trial. Neuropsychopharmacol. 2009 Feb;34(3):672-80.

72 Lynch ME, Ware MA. Cannabinoids for the treatment of chronic non-cancer pain: an updated systematic review of randomized controlled trials. J Neuroimmune Pharmacol. 2015 Jun;10(2):293-301.

73 Côté M, Trudel M, Wang C, Fortin A. Improving quality of life with nabilone during radiotherapy treatments for head and neck cancers: a randomized double-blind placebocontrolled trial. Ann Otol Rhinol Laryngol. 2016 Apr;125(4):317-24

74 Fallon M, Lux E, McQuade R, Rosetti S, Sanchez R, Sun W, et al. Sativex oromucosal spray as adjunctive therapy in advanced cancer patients with chronic pain unalleviated by optimized opioid therapy: two double-blind, randomized, placebo-controlled phase 3 studies. Br J Pain. 2017;11(3):119-33.

75 Fitzcharles MA, Baerwald C, Ablin J, Häuser W. Efficacy, tolerability and safety of cannabinoids in chronic pain associated with rheumatic diseases (fibromyalgia syndrome, back pain, osteoarthritis, rheumatoid arthritis): a systematic review of randomized controlled trials. Schmerz. 2016 Feb;30(1):47-61. 
76 Ware MA, Fitzcharles MA, Joseph L, Shir Y. The effects of nabilone on sleep in fibromyalgia: results of a randomized controlled trial. Anesth Analg. 2010 Feb;110(2):604-10.

77 Pini LA, Guerzoni S, Cainazzo MM, Ferrari A, Sarchielli P, Tiraferri I, et al. Nabilone for the treatment of medication overuse headache: results of a preliminary double-blind, activecontrolled, randomized trial. J Headache Pain. 2012 Nov;13(8):677-84.

78 Bertolini A, Ferrari A, Ottani A, Guerzoni S, Tacchi R, Leone S. Paracetamol: new vistas of an old drug. CNS Drug Rev. 2006;12(3-4): $250-75$.

79 Karussis D. The diagnosis of multiple sclerosis and the various related demyelinating syndromes: a critical review. J Autoimmun. 2014; 48-49:134-42.

80 Belbasis L, Bellou V, Evangelou E, Ioannidis JP, Tzoulaki I. Environmental risk factors and multiple sclerosis: an umbrella review of systematic reviews and meta-analyses. Lancet Neurol. 2015 Mar;14(3):263-73.

81 Cristino L, Bisogno T, Di Marzo V. Cannabinoids and the expanded endocannabinoid system in neurological disorders. Nat Rev Neurol. 2020;16(1):9-29.

82 Pryce G, Baker D. Endocannabinoids in multiple sclerosis and amyotrophic lateral sclerosis. Handb Exp Pharmacol. 2015;231:213-31.

83 Ball S, Vickery J, Hobart J, Wright D, Green $\mathrm{C}$, Shearer J, et al. The cannabinoid use in progressive inflammatory brain disease (CUPID) trial: a randomised double-blind placebocontrolled parallel-group multicentre trial and economic evaluation of cannabinoids to slow progression in multiple sclerosis. Health Technol Assess. 2015 Feb;19(12):1-187.

84 Iskedjian M, Bereza B, Gordon A, Piwko C, Einarson TR. Meta-analysis of cannabis based treatments for neuropathic and multiple sclerosis-related pain. Curr Med Res Opin. 2007 Jan;23(1):17-24.

85 Novotna A, Mares J, Ratcliffe S, Novakova I, Vachova M, Zapletalova O, et al. A randomized, double-blind, placebo-controlled, parallel-group, enriched-design study of nabiximols* (Sativex $\left[^{\circ}\right]$ ), as add-on therapy, in subjects with refractory spasticity caused by multiple sclerosis. Eur J Neurol. 2011 Sep; 18(9):1122-31.

86 Langford RM, Mares J, Novotna A, Vachova M, Novakova I, Notcutt W, et al. A doubleblind, randomized, placebo-controlled, parallel-group study of THC/CBD oromucosal spray in combination with the existing treatment regimen, in the relief of central neuropathic pain in patients with multiple sclerosis. J Neurol. 2013 Apr;260(4):984-97.

87 Stafstrom CE, Carmant L. Seizures and epilepsy: an overview for neuroscientists. Cold Spring Harb Perspect Med. 2015 Jun;5(6): a022426.

88 Gaston TE, Friedman D. Pharmacology of cannabinoids in the treatment of epilepsy. Epilepsy Behav. 2017 Jan;70(Pt B):313.
89 Gaston TE, Martin RC, Szaflarski JP. Cannabidiol (CBD) and cognition in epilepsy. Epilepsy Behav. 2021 Sep 23;124:108316.

90 Rosenberg EC, Tsien RW, Whalley BJ, Devinsky O. Cannabinoids and epilepsy. Neurotherapeutics. 2015 Oct;12(4):747-68.

91 Devinsky O, Marsh E, Friedman D, Thiele E, Laux L, Sullivan J, et al. Cannabidiol in patients with treatment-resistant epilepsy: an open-label interventional trial. Lancet Neurol. 2016 Mar;15(3):270-8.

92 Hess EJ, Moody KA, Geffrey AL, Pollack SF, Skirvin LA, Bruno PL, et al. Cannabidiol as a new treatment for drug-resistant epilepsy in tuberous sclerosis complex. Epilepsia. 2016 Oct;57(10):1617-24.

93 Devinsky O, Cross JH, Laux L, Marsh E, Miller I, Nabbout R, et al. Trial of cannabidiol for drug-resistant seizures in the dravet syndrome. N Engl J Med. 2017;376(21): 2011-20.

94 Salameh JS, Brown RH, Berry JD. Amyotrophic lateral sclerosis: review. Semin Neurol. 2015 Aug;35(4):469-76.

95 Urbi B, Owusu MA, Hughes I, Katz M, Broadley S, Sabet A. Effects of cannabinoids in amyotrophic lateral sclerosis (ALS) murine models: a systematic review and metaanalysis. J Neurochem. 2019 04;149(2):28497.

96 Weber M, Goldman B, Truniger S. Tetrahydrocannabinol (THC) for cramps in amyotrophic lateral sclerosis: a randomised, double-blind crossover trial. J Neurol Neurosurg Psychiatry. 2010 Oct;81(10):1135-40.

97 Lou K, Murphy S, Talbot C. Cannabinoids for the treatment of refractory neuropathic pruritus in amyotrophic lateral sclerosis: a case report. Palliat Med. 2021 Sep 11: 2692163211045314

98 Riva N, Mora G, Sorarù G, Lunetta C, Ferraro OE, Falzone Y, et al. Safety and efficacy of nabiximols on spasticity symptoms in patients with motor neuron disease (CANALS): a multicentre, double-blind, randomised, placebo-controlled, phase 2 trial. Lancet Neurol. 2019;18(2):155-64.

99 Kalia LV, Lang AE. Parkinson's disease. Lancet. 2015 Aug;386(9996):896-912.

100 Thanabalasingam SJ, Ranjith B, Jackson R, Wijeratne DT. Cannabis and its derivatives for the use of motor symptoms in Parkinson's disease: a systematic review and metaanalysis. Ther Adv Neurol Disord. 2021;14: 17562864211018561.

101 Sieradzan KA, Fox SH, Hill M, Dick JP, Crossman AR, Brotchie JM. Cannabinoids reduce levodopa-induced dyskinesia in Parkinson's disease: a pilot study. Neurology. 2001 Dec;57(11):2108-11.

102 Carroll CB, Bain PG, Teare L, Liu X, Joint C, Wroath $\mathrm{C}$, et al. Cannabis for dyskinesia in Parkinson disease: a randomized doubleblind crossover study. Neurology. 2004 Oct; 63(7):1245-50.
103 Peball M, Krismer F, Knaus HG, Djamshidian A, Werkmann M, Carbone F, et al. Nonmotor symptoms in Parkinson's disease are reduced by nabilone. Ann Neurol. 2020; 88(4):712-22.

104 Chagas MH, Zuardi AW, Tumas V, PenaPereira MA, Sobreira ET, Bergamaschi MM, et al. Effects of cannabidiol in the treatment of patients with Parkinson's disease: an exploratory double-blind trial. J Psychopharmacol. 2014 Nov;28(11):1088-98.

105 Heumann R, Moratalla R, Herrero MT, Chakrabarty K, Drucker-Colín R, GarciaMontes JR, et al. Dyskinesia in Parkinson's disease: mechanisms and current non-pharmacological interventions. J Neurochem. 2014 Aug;130(4):472-89.

106 Ross C, Tabrizi S. Huntington's disease from molecular pathogenesis to clinical treatment. Lancet. 2011;10(1):83-98.

107 Gövert F, Schneider S. Huntington's disease and Huntington's disease-like syndromes an overview. Cur Opi Neurol. 2013;26(4): 420-7.

108 Laprairie R, Bagher A, Precious S, DuncanWright E. Components of the endocannabinoid and dopamine systems are dysregulated in Huntington's disease: analysis of publicly available microarray datasets. Pharmacol Res Perspect. 2015;3(1):e00104.

109 Consroe P, Laguna J, Allender J, Snider S, Stern L, Sandy R, et al. Controlled clinical trial of cannabidiol in Huntington's disease. Pharmacol Biochem Behav. 1991;40(3): 701-8.

110 Moreno J, Caldentey J, Cubillo P, Romero C, Ribas G, Arias M, et al. A double-blind, randomized, cross-over, placebo-controlled, pilot trial with Sativex in Huntington's disease. J Neurol. 2016;263(7):1390-400.

111 Curtis A, Mitchell I, Patel S, Ives N, Rickards $\mathrm{H}$. A pilot study using nabilone for symptomatic treatment in Huntington's disease. Mov Disord. 2009;24(15):2254-9.

112 Pooyania S, Ethans K, Szturm T, Casey A Perry D. A randomized, double-blinded, crossover pilot study assessing the effect of nabilone on spasticity in persons with spinal cord injury. Arch Phys Med Rehabil. 2010 May;91(5):703-7.

113 Wissel J, Haydn T, Müller J, Brenneis C, Berger T, Poewe $\mathrm{W}$, et al. Low dose treatment with the synthetic cannabinoid Nabilone significantly reduces spasticity-related pain : a double-blind placebo-controlled cross-over trial. J Neurol. 2006;253(10): 1337-41.

114 Hagenbach U, Luz S, Ghafoor N, Berger JM, Grotenhermen F, Brenneisen R, et al. The treatment of spasticity with Delta9-tetrahydrocannabinol in persons with spinal cord injury. Spinal Cord. 2007 Aug;45(8):551-62.

115 Rintala DH, Fiess RN, Tan G, Holmes SA Bruel BM. Effect of dronabinol on central neuropathic pain after spinal cord injury: a pilot study. Am J Phys Med Rehabil. 2010 Oct;89(10):840-8. 
116 Bisson JI, Cosgrove S, Lewis C, Robert NP. Post-traumatic stress disorder. BMJ. 2015 Nov;351:h6161.

117 Betthauser K, Pilz J, Vollmer LE. Use and effects of cannabinoids in military veterans with posttraumatic stress disorder. Am J Health Syst Pharm. 2015 Aug;72(15):127984

118 Jetly R, Heber A, Fraser G, Boisvert D. The efficacy of nabilone, a synthetic cannabinoid, in the treatment of PTSD-associated nightmares: A preliminary randomized, double-blind, placebo-controlled cross-over design study. Psychoneuroendocrinol. 2015 Jan;51:585-8.

119 Kosiba JD, Maisto SA, Ditre JW. Patient-reported use of medical cannabis for pain, anxiety, and depression symptoms: systematic review and meta-analysis. Soc Sci Med. 2019 07;233:181-92.

120 Schlag AK, O'Sullivan SE, Zafar RR, Nutt DJ. Current controversies in medical cannabis: recent developments in human clinical applications and potential therapeutics. Neuropharmacol. 2021 May;191:108586.

121 Graczyk M, Łukowicz M, Dzierzanowski T. Prospects for the use of cannabinoids in psychiatric disorders. Front Psychiatry. 2021; 12:620073.

122 Rutkowska M, Jamontt J, Gliniak H. Effects of cannabinoids on the anxiety-like response in mice. Pharmacol Rep. 2006;58(2):200-6.

123 Naderi N, Haghparast A, Saber-Tehrani A, Rezaii N, Alizadeh AM, Khani A, et al. Interaction between cannabinoid compounds and diazepam on anxiety-like behaviour of mice. Pharmacol Biochem Behav. 2008 Mar; 89(1):64-75.

124 Bergamaschi MM, Queiroz RH, Chagas $\mathrm{MH}$, de Oliveira DC, De Martinis BS, Kapczinski $F$, et al. Cannabidiol reduces the anxiety induced by simulated public speaking in treatment-naïve social phobia patients. Neuropsychopharmacol. 2011 May;36(6): 1219-26.

125 Turna J, Patterson B, Van Ameringen M. Is cannabis treatment for anxiety, mood, and related disorders ready for prime time? Depress Anxiety. 2017 11;34(11):1006-17.

126 Onaivi ES, Green MR, Martin BR. Pharmacological characterization of cannabinoids in the elevated plus maze. J Pharmacol Exp Ther. 1990 Jun;253(3):1002-9.

127 Moreira FA, Lutz B. The endocannabinoid system: emotion, learning and addiction. Addict Biol. 2008 Jun;13(2):196-212.

128 Botsford SL, Yang S, George TP. Cannabis and cannabinoids in mood and anxiety disorders: impact on illness onset and course, and assessment of therapeutic potential. Am J Addict. 2020 01;29(1):9-26.

129 Crippa JA, Zuardi AW, Martín-Santos R, Bhattacharyya S, Atakan Z, McGuire P, et al. Cannabis and anxiety: a critical review of the evidence. Hum Psychopharmacol. 2009 Oct; 24(7):515-23.
130 Bhattacharyya S, Egerton A, Kim E, Rosso L, Riano Barros D, Hammers A, et al. Acute induction of anxiety in humans by delta-9-tetrahydrocannabinol related to amygdalar cannabinoid-1 (CB1) receptors. Sci Rep. 2017;7(1):15025.

131 Corroon J, Phillips JA. A cross-sectional study of cannabidiol users. Cannabis Cannabinoid Res. 2018;3(1):152-61.

132 Moltke J, Hindocha C. Reasons for cannabidiol use: a cross-sectional study of CBD users, focusing on self-perceived stress, anxiety, and sleep problems. J Cannabis Res. $2021 \mathrm{Feb} ; 3(1): 5$

133 Monti JM. Hypnoticlike effects of cannabidiol in the rat. Psychopharmacol. 1977 Dec; 55(3):263-5.

134 Murillo-Rodríguez E, Millán-Aldaco D, Palomero-Rivero M, Mechoulam R, Drucker-Colín R. Cannabidiol, a constituent of Cannabis sativa, modulates sleep in rats. FEBS Lett. 2006 Aug;580(18):4337-45.

135 Chagas MH, Crippa JA, Zuardi AW, Hallak JE, Machado-de-Sousa JP, Hirotsu C, et al. Effects of acute systemic administration of cannabidiol on sleep-wake cycle in rats. J Psychopharmacol. 2013 Mar;27(3):312-6.

136 Murillo-Rodríguez E, Millán-Aldaco D, Cicconcelli D, Giorgetti V, ArankowskySandoval G, Alcaraz-Silva J, et al. Sleep-wake cycle disturbances and NeuN-altered expression in adult rats after cannabidiol treatments during adolescence. Psychopharmacol. $2021 \mathrm{Feb} ; 238(6): 1437$.

137 Kaul M, Zee PC, Sahni AS. Effects of cannabinoids on sleep and their therapeutic potential for sleep disorders. Neurotherapeutics. 2021 Jan;18(1):217-27.

138 Morel A, Lebard P, Dereux A, Azuar J, Questel F, Bellivier F, et al. Clinical trials of cannabidiol for substance use disorders: outcome measures, surrogate endpoints, and biomarkers. Front Psychiatry. 2021;12: 565617.

139 Rosic T, Kapoor R, Panesar B, Naji L, Chai $\mathrm{DB}$, Sanger N, et al. The association between cannabis use and outcome in pharmacological treatment for opioid use disorder. Harm Reduct J. 2021 Feb;18(1):24.

140 Wesson DR, Ling W. The clinical opiate withdrawal scale (COWS). J Psychoactive Drugs. 2003 Apr;35(2):253-9.

141 Hurd YL, Spriggs S, Alishayev J, Winkel G, Gurgov K, Kudrich C, et al. Cannabidiol for the reduction of cue-induced craving and anxiety in drug-abstinent individuals with heroin use disorder: a double-blind randomized placebo-controlled trial. Am J Psychiatry. 2019;176(11):911-22.

142 Sloan ME, Gowin JL, Ramchandani VA, Hurd YL, Le Foll B. The endocannabinoid system as a target for addiction treatment: trials and tribulations. Neuropharmacol. 2017 Sep 15;124:73-83.
143 Milosev LM, Psathakis N, Szejko N, Jakubovski E, Müller-Vahl KR. Treatment of gilles de la tourette syndrome with cannabis-based medicine: results from a retrospective analysis and online survey. Cannabis Cannabinoid Res. 2019;4(4):265-74.

144 Koppel BS. Cannabis in the treatment of dystonia, dyskinesias, and tics. Neurotherapeutics. 2015 Oct; 12(4):788-92.

145 Müller-Vahl KR, Schneider U, Koblenz A, Jöbges M, Kolbe H, Daldrup T, et al. Treatment of Tourette's syndrome with Delta 9-tetrahydrocannabinol (THC): a randomized crossover trial. Pharmacopsychiatry. 2002 Mar;35(2):57-61.

146 Müller-Vahl KR, Schneider U, Prevedel H, Theloe K, Kolbe H, Daldrup T, et al. Delta 9-tetrahydrocannabinol (THC) is effective in the treatment of tics in Tourette syndrome: a 6-week randomized trial. J Clin Psychiatry. 2003 Apr;64(4):459-65.

147 Jakubovski E, Pisarenko A, Fremer C, Haas M, May M, Schumacher C, et al. The CANNA-TICS study protocol: a randomized multi-center double-blind placebo controlled trial to demonstrate the efficacy and safety of nabiximols in the treatment of adults with chronic tic disorders. Front Psychiatry. 2020;11:575826.

148 Navari RM. Management of chemotherapyinduced nausea and vomiting: focus on newer agents and new uses for older agents. Drugs. 2013;73(3):249-62.

149 Argilés JM, Busquets S, Stemmler B, LópezSoriano FJ. Cancer cachexia: understanding the molecular basis. Nat Rev Cancer. 2014 Nov; 14(11):754-62.

150 Sharkey KA, Cristino L, Oland LD, Van Sickle MD, Starowicz K, Pittman QJ, et al. Arvanil, anandamide and $\mathrm{N}$-arachidonoyldopamine (NADA) inhibit emesis through cannabinoid CB1 and vanilloid TRPV1 receptors in the ferret. Eur J Neurosci. 2007 May;25(9):2773-82.

151 Sticht MA, Rock EM, Limebeer CL, Parker LA. Endocannabinoid mechanisms influencing nausea. Int Rev Neurobiol. 2015;125: 127.

152 Kleine-Brueggeney M, Greif R, Brenneisen R, Urwyler N, Stueber F, Theiler LG. Intravenous delta-9-tetrahydrocannabinol to prevent postoperative nausea and vomiting: a randomized controlled trial. Anesth Analg. 2015 Nov; 121(5):1157-64.

153 Kramer JL. Medical marijuana for cancer. CA Cancer J Clin. 2015 Mar;65(2):109-22.

154 Omuro A, DeAngelis LM. Glioblastoma and other malignant gliomas: a clinical review. JAMA. 2013 Nov;310(17):1842-50.

155 Blázquez C, González-Feria L, Alvarez L, Haro A, Casanova ML, Guzmán M. Cannabinoids inhibit the vascular endothelial growth factor pathway in gliomas. Cancer Res. 2004 Aug;64(16):5617-23. 
156 Torres S, Lorente M, Rodríguez-Fornés F, Hernández-Tiedra S, Salazar M, GarcíaTaboada E, et al. A combined preclinical therapy of cannabinoids and temozolomide against glioma. Mol Cancer Ther. 2011 Jan; 10(1):90-103.

157 Rocha FC, Dos Santos Júnior JG, Stefano SC, da Silveira DX. Systematic review of the literature on clinical and experimental trials on the antitumor effects of cannabinoids in gliomas. J Neurooncol. 2014 Jan;116(1):1124.

158 Fanali C, Lucchetti D, Farina M, Corbi M, Cufino V, Cittadini A, et al. Cancer stem cells in colorectal cancer from pathogenesis to therapy: controversies and perspectives. World J Gastroenterol. 2014 Jan;20(4):92342.

159 Zeuner A, Todaro M, Stassi G, De Maria R. Colorectal cancer stem cells: from the crypt to the clinic. Cell Stem Cell. 2014 Dec;15(6): 692-705.

160 Cudaback E, Marrs W, Moeller T, Stella N. The expression level of $\mathrm{CB} 1$ and $\mathrm{CB} 2$ receptors determines their efficacy at inducing apoptosis in astrocytomas. PLoS One. 2010 Jan;5(1):e8702.

161 Gazzerro P, Malfitano AM, Proto MC, Santoro A, Pisanti S, Caruso MG, et al. Synergistic inhibition of human colon cancer cell growth by the cannabinoid CB1 receptor antagonist rimonabant and oxaliplatin. Oncol Rep. 2010 Jan;23(1):171-5.

162 Gustafsson SB, Palmqvist R, Henriksson ML, Dahlin AM, Edin S, Jacobsson SO, et al. High tumour cannabinoid CB1 receptor immunoreactivity negatively impacts diseasespecific survival in stage II microsatellite stable colorectal cancer. PLoS One. 2011;6(8): e23003.

163 Gustafsson SB, Lindgren T, Jonsson M, Jacobsson SO. Cannabinoid receptor-independent cytotoxic effects of cannabinoids in human colorectal carcinoma cells: synergism with 5-fluorouracil. Cancer Chemother Pharmacol. 2009 Mar;63(4):691-701.

164 Raup-Konsavage WM, Johnson M, Legare CA, Yochum GS, Morgan DJ, Vrana KE. Synthetic cannabinoid activity against colorectal cancer cells. Cannabis Cannabinoid Res. 2018;3(1):272-81.

165 Vincent A, Herman J, Schulick R, Hruban RH, Goggins M. Pancreatic cancer. Lancet. 2011 Aug;378(9791):607-20.

166 Dando I, Donadelli M, Costanzo C, Dalla Pozza E, D’Alessandro A, Zolla L, et al. Cannabinoids inhibit energetic metabolism and induce AMPK-dependent autophagy in pancreatic cancer cells. Cell Death Dis. 2013 Jun;4:e664.

167 Michalski CW, Oti FE, Erkan M, Sauliunaite D, Bergmann F, Pacher P, et al. Cannabinoids in pancreatic cancer: correlation with survival and pain. Int J Cancer. 2008 Feb; 122(4):742-50.
168 Kiagia M, Syrigos KN, Saif MW. Quality of life in patients with pancreatic cancer. JOP. 2014 Jul;15(4):317-8.

169 Chakravarti B, Ravi J, Ganju RK. Cannabinoids as therapeutic agents in cancer: current status and future implications. Oncotarget. 2014 Aug;5(15):5852-72.

170 Redig AJ, McAllister SS. Breast cancer as a systemic disease: a view of metastasis. J Intern Med. 2013 Aug;274(2):113-26.

171 Bodai BI, Tuso P. Breast cancer survivorship: a comprehensive review of long-term medical issues and lifestyle recommendations. Perm J. 2015;19(2):48-79.

172 Bisogno T, Hanus L, De Petrocellis L, Tchilibon S, Ponde DE, Brandi I, et al. Molecular targets for cannabidiol and its synthetic analogues: effect on vanilloid VR1 receptors and on the cellular uptake and enzymatic hydrolysis of anandamide. Br J Pharmacol. 2001 Oct;134(4):845-52.

173 McAllister SD, Murase R, Christian RT, Lau D, Zielinski AJ, Allison J, et al. Pathways mediating the effects of cannabidiol on the reduction of breast cancer cell proliferation, invasion, and metastasis. Breast Cancer Res Treat. 2011 Aug;129(1):37-47.

174 Elbaz M, Nasser MW, Ravi J, Wani NA, Ahirwar DK, Zhao H, et al. Modulation of the tumor microenvironment and inhibition of EGF/EGFR pathway: novel anti-tumor mechanisms of Cannabidiol in breast cancer. Mol Oncol. 2015 Apr;9(4):906-19.

175 Weinreb RN, Aung T, Medeiros FA. The pathophysiology and treatment of glaucoma: a review. JAMA. 2014 May;311(18): 1901-11.

176 Porcella A, Maxia C, Gessa GL, Pani L. The synthetic cannabinoid WIN55212-2 decreases the intraocular pressure in human glaucoma resistant to conventional therapies. Eur J Neurosci. 2001 Jan;13(2):409-12.

177 Tomida I, Azuara-Blanco A, House H, Flint M, Pertwee RG, Robson PJ. Effect of sublingual application of cannabinoids on intraocular pressure: a pilot study. J Glaucoma. 2006 Oct;15(5):349-53.

178 Novack GD. Cannabinoids for treatment of glaucoma. Curr Opin Ophthalmol. 2016 Mar;27(2):146-50.

179 Ahmed W, Katz S. Therapeutic use of cannabis in inflammatory bowel disease. Gastroenterol Hepatol. 2016 Nov;12(11):66879 .

180 Bogale K, Raup-Konsavage W, Dalessio S, Vrana K, Coates MD. Cannabis and cannabis derivatives for abdominal pain management in inflammatory bowel disease. Med Cannabis Cannabinoids. 2021;4(2):1.

181 Coates MD, Dalessio S, Walter V, Stuart A, Bernasko N, Tinsley A, et al. Symptoms and extraintestinal manifestations in active cannabis users with inflammatory bowel disease. Cannabis Cannabinoid Res. 2021 Mar.
182 Naftali T, Bar-Lev Schneider L, Dotan I, Lansky E, Sklerovsky Benjaminov F, Konikoff $F$. Cannabis induces a clinical response in patients with Crohn's disease: a prospective placebo-controlled study. Clin Gastroenterol Hepatol Symptoms and extraintestinal manifestations in active cannabis users with inflammatory bowel disease. 2013; 11(10):1276-80.

183 Storr M, Devlin S, Kaplan GG, Panaccione $\mathrm{R}$, Andrews CN. Cannabis use provides symptom relief in patients with inflammatory bowel disease but is associated with worse disease prognosis in patients with Crohn's disease. Inflamm Bowel Dis. 2014 Mar;20(3):472-80.

184 Substance Abuse and Mental Health Services Administration. Behavioral health trends in the United States: results from the 2014 National survey on drug use and health; 2015.

185 Hung CC, Chang HY, Luh DL, Wu CC, Yen LL. Do parents play different roles in drinking behaviours of male and female adolescents? A longitudinal follow-up study. BMJ Open. 2015 Apr;5(4):e007179.

186 Dhein S. Different effects of cannabis abuse on adolescent and adult brain. Pharmacology. 2020;105(11-12):609-17.

187 Blumentrath CG, Dohrmann B, Ewald N. Cannabinoid hyperemesis and the cyclic vomiting syndrome in adults: recognition, diagnosis, acute and long-term treatment. Ger Med Sci. 2017;15:Doc06.

188 Howard I. Cannabis hyperemesis syndrome in palliative care: a case study and narrative review. J Palliat Med. 2019;22(10):1227-31.

189 Chandra S, Radwan MM, Majumdar CG, Church JC, Freeman TP, ElSohly MA. New trends in cannabis potency in USA and Europe during the last decade (2008-2017). Eur Arch Psychiatry Clin Neurosci. 2019 Feb;269(1):5-15.

190 Wilson J, Freeman TP, Mackie CJ. Effects of increasing cannabis potency on adolescent health. Lancet Child Adolesc Health. 2019; 3(2):121-8.

191 Tamm L, Epstein JN, Lisdahl KM, Molina B, Tapert S, Hinshaw SP, et al. Impact of ADHD and cannabis use on executive functioning in young adults. Drug Alcohol Depend. 2013 Dec;133(2):607-14.

192 Dow-Edwards D, Silva L. Endocannabinoids in brain plasticity: cortical maturation, HPA axis function and behavior. Brain Res. 2017 Jan;1654(Pt B):157-64.

193 Meier MH, Caspi A, Ambler A, Harrington H, Houts R, Keefe RS, et al. Persistent cannabis users show neuropsychological decline from childhood to midlife. Proc Natl Acad Sci U S A. 2012 Oct;109(40):E2657-64.

194 Hebert-Chatelain E, Desprez T, Serrat R, Bellocchio L, Soria-Gomez E, Busquets-Garcia A, et al. A cannabinoid link between mitochondria and memory. Nature. 2016 11; 539(7630):555-9. 
195 Ranganathan M, Radhakrishnan R, Addy P, Schnakenberg-Martin A, Williams A, Carbuto M, et al. Tetrahydrocannabinol (THC) impairs encoding but not retrieval of verbal information. Prog Neuropsychopharmacol Biol Psychiatry. 2017;79(B):176-83.

196 Walpole SC, Prieto-Merino D, Edwards P, Cleland J, Stevens G, Roberts I. The weight of nations: an estimation of adult human biomass. BMC Public Health. 2012 Jun;12: 439.

197 D’Souza DC, Perry E, MacDougall L, Ammerman Y, Cooper T, Wu YT, et al. The psychotomimetic effects of intravenous delta9-tetrahydrocannabinol in healthy individuals: implications for psychosis. Neuropsychopharmacol. 2004 Aug;29(8): 1558-72.

198 Crane NA, Schuster RM, Gonzalez R. Preliminary evidence for a sex-specific relationship between amount of cannabis use and neurocognitive performance in young adult cannabis users. J Int Neuropsychol Soc. 2013 Oct;19(9):1009-15.

199 Crane NA, Schuster RM, Mermelstein RJ, Gonzalez R. Neuropsychological sex differences associated with age of initiated use among young adult cannabis users. J Clin Exp Neuropsychol. 2015;37(4):389-401.

200 Cloak CC, Alicata D, Ernst TM, Chang L. Psychiatric symptoms, salivary cortisol and cytokine levels in young marijuana users. J Neuroimmune Pharmacol. 2015 Jun;10(2): 380-90.

201 Arseneault L, Cannon M, Poulton R, Murray R, Caspi A, Moffitt TE. Cannabis use in adolescence and risk for adult psychosis: longitudinal prospective study. BMJ. 2002 Nov; 325(7374):1212-3.

202 Henquet C, Rosa A, Krabbendam L, Papiol S, Fananás L, Drukker M, et al. An experimental study of catechol-o-methyltransferase Val158Met moderation of delta-9-tetrahydrocannabinol-induced effects on psychosis and cognition. Neuropsychopharmacol. 2006 Dec;31(12):2748-57.

203 Jutras-Aswad D, Jacobs MM, Yiannoulos G, Roussos P, Bitsios P, Nomura Y, et al. Cannabis-dependence risk relates to synergism between neuroticism and proenkephalin SNPs associated with amygdala gene expression: case-control study. PLoS One. 2012; 7(6):e39243.

204 Bidwell LC, Metrik J, McGeary J, Palmer RH, Francazio S, Knopik VS. Impulsivity, variation in the cannabinoid receptor (CNR1) and fatty acid amide hydrolase (FAAH) genes, and marijuana-related problems. J Stud Alcohol Drugs. 2013 Nov;74(6): 867-78.

205 Sherif M, Radhakrishnan R, D'Souza DC, Ranganathan M. Human laboratory studies on cannabinoids and psychosis. Biol Psychiatry. $2016 \mathrm{Apr} ; 79(7): 526-38$.
206 Franklin JM, Carrasco GA. G-protein receptor kinase 5 regulates the cannabinoid receptor 2-induced up-regulation of serotonin $2 \mathrm{~A}$ receptors. J Biol Chem. 2013 May;288(22): 15712-24.

207 Wilkinson ST, Radhakrishnan R, D'Souza DC. Impact of Cannabis use on the development of psychotic disorders. Curr Addict Rep. 2014 Jun;1(2):115-28.

208 D'Souza DC, Radhakrishnan R, Sherif M, Cortes-Briones J, Cahill J, Gupta S, et al. Cannabinoids and psychosis. Curr Pharm Des. 2016;22(42):6380-91.

209 Ganesh S, Cortes-Briones J, Ranganathan M, Radhakrishnan R, Skosnik PD, D'Souza DC. Psychosis-relevant effects of intravenous delta-9-tetrahydrocannabinol: a mega analysis of individual participant-data from human laboratory studies. Int J Neuropsychopharmacol. 2020 Dec;23(9): 559-70.

210 Hindley G, Beck K, Borgan F, Ginestet CE, McCutcheon R, Kleinloog D, et al. Psychiatric symptoms caused by cannabis constituents: a systematic review and meta-analysis. Lancet Psychiatry. 2020;7(4):344-53.

211 Marconi A, Di Forti M, Lewis CM, Murray RM, Vassos E. Meta-analysis of the association between the level of cannabis use and risk of psychosis. Schizophr Bull. 2016 09; 42(5):1262-9.

212 Gibbs M, Winsper C, Marwaha S, Gilbert E, Broome M, Singh SP. Cannabis use and mania symptoms: a systematic review and meta-analysis. J Affect Disord. 2015 Jan;171: 39-47.

213 Zammit S, Allebeck P, Andreasson S, Lundberg I, Lewis G. Self reported cannabis use as a risk factor for schizophrenia in Swedish conscripts of 1969: historical cohort study. BMJ. 2002 Nov;325(7374):1199.

214 Manrique-Garcia E, Zammit S, Dalman C, Hemmingsson T, Andreasson S, Allebeck P. Cannabis, schizophrenia and other non-affective psychoses: 35 years of follow-up of a population-based cohort. Psychol Med. 2012 Jun;42(6):1321-8.

215 van Os J, Bak M, Hanssen M, Bijl RV, de Graaf R, Verdoux H. Cannabis use and psychosis: a longitudinal population-based study. Am J Epidemiol. 2002 Aug;156(4): 319-27.

216 Kuepper R, van Os J, Lieb R, Wittchen HU, Höfler M, Henquet C. Continued cannabis use and risk of incidence and persistence of psychotic symptoms: 10 year follow-up cohort study. BMJ. 2011 Mar;342:d738.

217 Zuardi AW, Shirakawa I, Finkelfarb E, Karniol IG. Action of cannabidiol on the anxiety and other effects produced by delta 9-THC in normal subjects. Psychopharmacol. 1982; 76(3):245-50.

218 Moreira FA, Guimarães FS. Cannabidiol inhibits the hyperlocomotion induced by psychotomimetic drugs in mice. Eur J Pharmacol. 2005 Apr 11;512(2-3):199-205.
219 Leweke FM, Piomelli D, Pahlisch F, Muhl D, Gerth CW, Hoyer C, et al. Cannabidiol enhances anandamide signaling and alleviates psychotic symptoms of schizophrenia. Transl Psychiatry. 2012 Mar 20;2:e94.

220 Gomes FV, Llorente R, Del Bel EA, Viveros MP, López-Gallardo M, Guimarães FS. Decreased glial reactivity could be involved in the antipsychotic-like effect of cannabidiol. Schizophr Res. 2015 May;164(1-3):155-63.

221 Zuardi AW, Hallak JE, Dursun SM, Morais SL, Sanches RF, Musty RE, et al. Cannabidiol monotherapy for treatment-resistant schizophrenia. J Psychopharmacol. 2006 Sep;20(5):683-6.

222 Boggs DL, Surti T, Gupta A, Gupta S, Niciu M, Pittman B, et al. The effects of cannabidiol (CBD) on cognition and symptoms in outpatients with chronic schizophrenia a randomized placebo controlled trial. Psychopharmacol. 2018 07;235(7):1923-32.

223 Boehnke KF, Litinas E, Clauw DJ. Medical cannabis use is associated with decreased opiate medication use in a retrospective cross-sectional survey of patients with chronic pain. J Pain. 2016 Jun;17(6):739-44.

224 Korzh A, Keren O, Gafni M, Bar-Josef H, Sarne Y. Modulation of extracellular signalregulated kinase (ERK) by opioid and cannabinoid receptors that are expressed in the same cell. Brain Res. 2008 Jan;1189:23-32.

225 Scavone JL, Sterling RC, Van Bockstaele EJ. Cannabinoid and opioid interactions: implications for opiate dependence and withdrawal. Neuroscience. 2013 Sep;248:637-54.

226 Kinghorn A, Falk H, Gibbons S, Kobayashi J. Phytocannabinoids: Springer; 2017.

227 Abrams DI, Couey P, Shade SB, Kelly ME, Benowitz NL. Cannabinoid-opioid interaction in chronic pain. Clin Pharmacol Ther. 2011 Dec;90(6):844-51.

228 Throckmorton D. FDA regulation of marijuana: past actions, future plans: Food and Drug Administration: FDA; 2016.

229 Dalton WS, Martz R, Lemberger L, Rodda $\mathrm{BE}$, Forney RB. Influence of cannabidiol on delta-9-tetrahydrocannabinol effects. Clin Pharmacol Ther. 1976 Mar;19(3):300-9.

230 Szaflarski JP, Bebin EM. Cannabis, cannabidiol, and epilepsy--from receptors to clinical response. Epilepsy Behav. 2014;41:277-82.

231 Hindocha C, Freeman TP, Schafer G, Gardener C, Das RK, Morgan CJ, et al. Acute effects of delta-9-tetrahydrocannabinol, cannabidiol and their combination on facial emotion recognition: a randomised, doubleblind, placebo-controlled study in cannabis users. Eur Neuropsychopharmacol. 2015 Mar;25(3):325-34.

232 Walentiny DM, Gamage TF, Warner JA, Nguyen TK, Grainger DB, Wiley JL, et al. The endogenous cannabinoid anandamide shares discriminative stimulus effects with $\Delta(9)$-tetrahydrocannabinol in fatty acid amide hydrolase knockout mice. Eur J Pharmacol. 2011 Apr;656(1-3):63-7. 
233 Bonn-Miller MO, Loflin MJE, Thomas BF, Marcu JP, Hyke T, Vandrey R. Labeling accuracy of cannabidiol extracts sold online. JAMA. 2017 Nov;318(17):1708-9.

234 Hazekamp A. The trouble with CBD oil. Med Cannabis Cannabinoids. 2018;1(1):6572.

235 Pavlovic R, Nenna G, Calvi L, Panseri S, Borgonovo G, Giupponi L, et al. Quality traits of "cannabidiol oils": cannabinoids content, terpene fingerprint and oxidation stability of European commercially available preparations. Molecules. 2018 May;23(5):1230.

236 Raup-Konsavage W, Carkaci-Salli N, Greenland K, Gearhart RJ, Vrana K. Cannabidiol (CBD) oil does not display an entourage effect in reducing cancer cell viability in vitro. Medical Cannabis Cannabinoids. 2020;3:95.

237 Ogawa S, Kunugi H. Inhibitors of fatty acid amide hydrolase and monoacylglycerol lipase: new targets for future antidepressants. Curr Neuropharmacol. 2015;13(6):760-75.

238 Pertwee RG. Pharmacological actions of cannabinoids. Handb Exp Pharmacol. 2005; 168(168):1-51.
239 Ryberg E, Larsson N, Sjögren S, Hjorth S, Hermansson NO, Leonova J, et al. The orphan receptor GPR55 is a novel cannabinoid receptor. Br J Pharmacol. 2007 Dec;152(7): 1092-101.

240 McPartland JM, Glass M, Pertwee RG. Meta-analysis of cannabinoid ligand binding affinity and receptor distribution: interspecies differences. Br J Pharmacol. 2007 Nov; 152(5):583-93.

241 Ross RA, Gibson TM, Brockie HC, Leslie M, Pashmi G, Craib SJ, et al. Structure-activity relationship for the endogenous cannabinoid, anandamide, and certain of its analogues at vanilloid receptors in transfected cells and vas deferens. Br J Pharmacol. 2001 Feb;132(3):631-40.

242 De Petrocellis L, Bisogno T, Maccarrone M, Davis JB, Finazzi-Agro A, Di Marzo V. The activity of anandamide at vanilloid VR1 receptors requires facilitated transport across the cell membrane and is limited by intracellular metabolism. J Biol Chem. 2001 Apr; 276(16):12856-63.
243 Huang H, McIntosh AL, Martin GG, Landrock $\mathrm{D}$, Chung $\mathrm{S}$, Landrock $\mathrm{KK}$, et al. FABP1: a novel hepatic endocannabinoid and cannabinoid binding protein. Biochemistry. 2016 Sep;55(37):5243-55.

244 Darmani NA, Sim-Selley LJ, Martin BR, Janoyan JJ, Crim JL, Parekh B, et al. Antiemetic and motor-depressive actions of CP55,940: cannabinoid CB1 receptor characterization, distribution, and G-protein activation. Eur J Pharmacol. 2003 Jan;459(1): 83-95.

245 Thomas A, Baillie GL, Phillips AM, Razdan RK, Ross RA, Pertwee RG. Cannabidiol displays unexpectedly high potency as an antagonist of $\mathrm{CB} 1$ and $\mathrm{CB} 2$ receptor agonists in vitro. Br J Pharmacol. 2007 Mar;150(5):61323.

246 Erdozain AM, Diez-Alarcia R, Meana JJ, Callado LF. The inverse agonist effect of rimonabant on $\mathrm{G}$ protein activation is not mediated by the cannabinoid $\mathrm{CB} 1$ receptor: evidence from postmortem human brain. Biochem Pharmacol. 2012;83(2):260. 